\title{
تنطيط نشر التربية الأمنية في المؤسسات التربوية العربية في ضوء الاتجاهات الهديثة في بناء المناهج
}

\section{د. سعيد بز محمل مزهر}

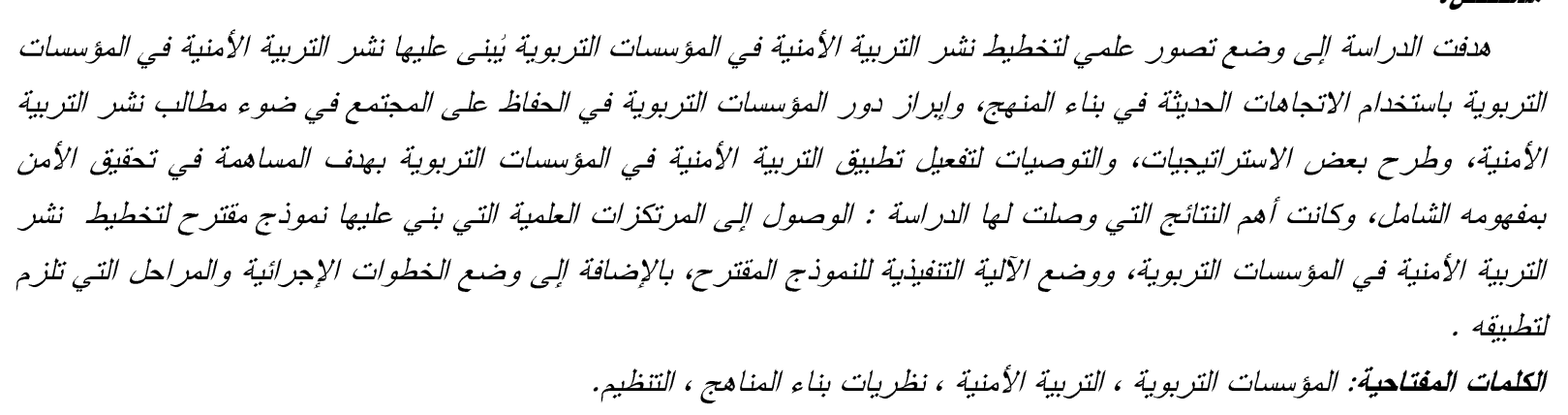

\section{Abstract:}

The study aimed to develop a scientific vision for planning the deployment of security education in educational institutions built upon the deployment of security education in educational institutions using modern trends in the construction of the curriculum, and to highlight the role of educational institutions in maintaining the community in the light of the demands of the deployment of security education, put some of the strategies and recommendations to activate the application security education in educational institutions in order to contribute to the achievement of security in its destruction, and the most important results reached her study: access to scientific foundations on which it is proposed to plan the deployment of security education in educational institutions model, and put the executive mechanism of the proposed model, in addition to developing the procedural steps and stages You are required to apply.

على النفس، ولا يخاف على العرض، ولا يخاف

الإطار العام للدراسة

على المال و لا على الحقوق، قال تعالى : (الَّذبي

المقدمــة :

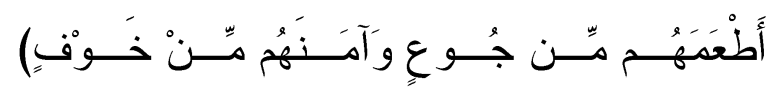

$$
\text { (قريش،الآية ع). }
$$

وقد جاءت التربية كجزء من منظومة المجتمع

لتؤكد على ذلك في مناهجها، ومقرراتها

وأنشطتها، وتسهح في مواجهة مشكلاته ، و لأن

التعليم يُعد أهم مقومات فهم التغيرات التي تحدث

بشكل عام، وفي عالمنا المعاصر بشكل خاص،

كونه يصل بالقرد إلى تغير أعمق كماً وكيفاً،

إضافة إلى تمكينه من تغيير مواقفه، و اتجاهاته

لارتباطه بسلوك الفرد، وامتلاكه أدوات

الاستيعاب، والتكيف مع المتغيرات الحادثة

حوله، بمعنى آخر أن هناك علاقة طردية بين

للأمن مكانة عظيمة في حياة الأمة، لذا جاء

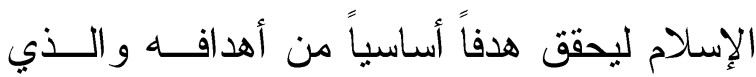

يتمثل في تحقيق الأمن لجميع أفــر اد المجتمــع ويبدل خوفهم إلى أمن، ويسعى إلى إرساء دعائم

الإسلام بتحقيق غاياته الجليلة المتعلقة بضرورة

توفير الأمن للإنسان كما هي حاجته إلى الطعام

و الشراب، بل رسم الإسلام المبادئ و الأسس التي

تتطلق منها تحقيق هذه الغاية العظيمة بكل دقة،

ووضوح، فأعظم النعم بعد الإيمان هي الأمــن،

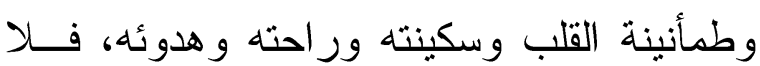

يخاف الإنسان مع الأمن على الدين، و لا يخاف ورله 


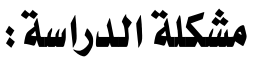

ترتبط المجتمعات المعاصرة على اختلاف أنظمتها السياسية بعديد من التحو لات، و التغيرات

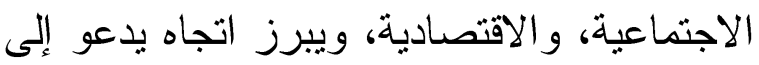
الاهتمام بالفاعلين الاجتماعيين سواء كانوا

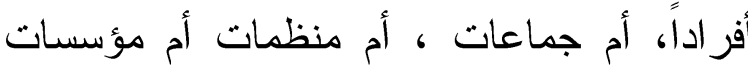
تربوية كالمدارس والجامعات، ومراكز البحث العلمي، وتفعيل دور هم التتموي وحجم مساهتهم في المشروع المجتمي للتعامل مع المشكلات المعاصرة، وتحقيق الوقاية من الأفعال التي تزعزع الاستقرار والأمن في مختلف أنثطة

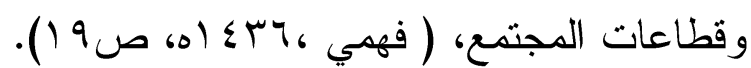
و التزبية بمفهومها الواسع في عصــرنا

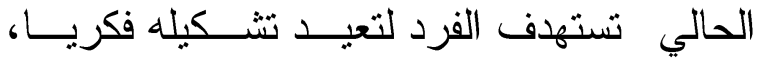

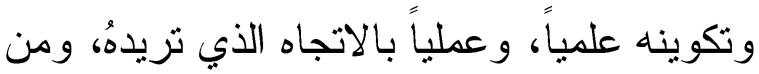

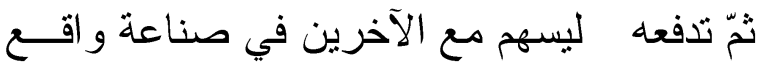

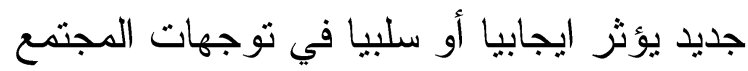
ومستقبله ، وتقوم بنشر القيم و المبادئ و المفاهيم

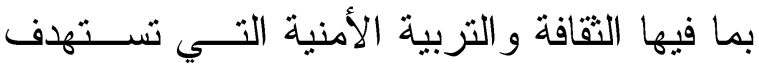

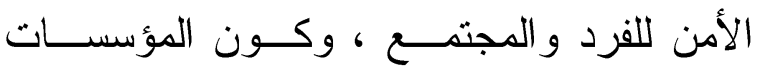

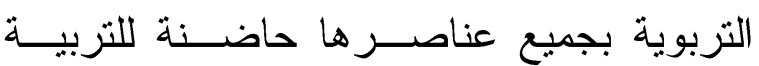
و التعليم، فإن دور ها البارز في عملية نشر الثقافة

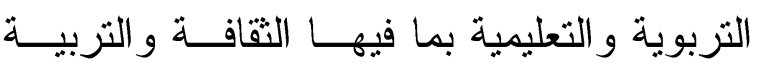
الأمنية كجزء منها يجب أن يكون وفـق رؤيــة علمية منهجية و اضحة. ولذللك فقد أكدت دراسات عديدة على أهمية المؤسسات التعليمية (المدارس و المعاهد و الجامعات ) بمنظومتها، وعناصر ها المتكاملة في بناء فكر الطالب، واعداده لمواجهة ظروف
كفاءة التعليم، وإجر اءات التغيير ،لذا سعت الكثير من الدول إلى إعادة النظر في نظمها التعليمية

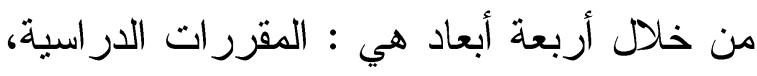
المعلم ، أدوات التعلم و التعليم ، و البيئة التعليمية،

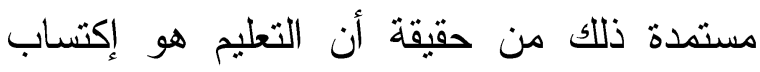
المعلومات من أجل اتخاذ قرارات التغيير

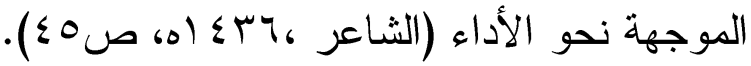
وما أحوجنا اليوم في المملكة العربية

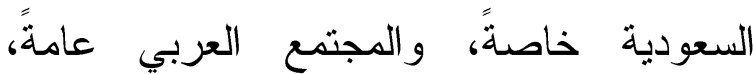
كغيرها من المجتمعات الإنسانية الأخرى التي تمر بمرحلة التحو لات السريعة والمتلاحقة التي التي شملت مختلف أوجه الحياة الاجتماعية و الاقتصادية و السياسية و الثقافية في التغيرات المعاصرة ، إلى أن نواجه هذه التحديات،

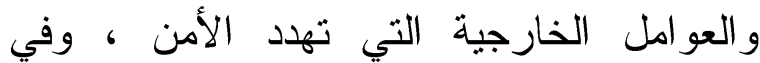
مقدمتها المدنية المعاصرة، ، و الجريمة المنظمة، و الفساد، والانحلال الخلقي، وانتشار المخدرات، و الإرهاب، و العولمة ، والبطالة ، و التغريب الثقافي، و الثورة الثقنية و المعلوماتية، و البث المباشر، و الإنترنت، و التبعية في التعليم، إلي جانب العوامل الداخلية المتمثلة في التفكك الأسري، و الكثافة السكانية، و البطالة، والأمية،

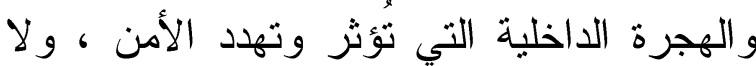
سبيل لمواجهة تلكك التحديات إلا بتربية وتعليم يجعلنا نستطيع مواجتها بما يجعل من الأجيال

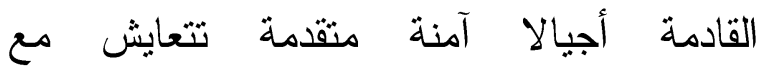
الحضار ات ، وتتأثر بها وتؤثر فيها ، مع التمسك لهات القوي بثو ابتتا ومعتقداتتا. 


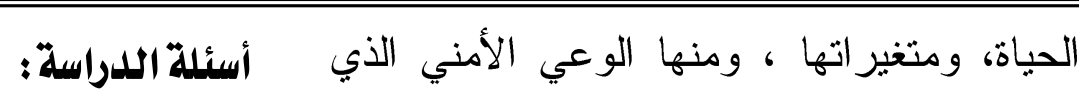

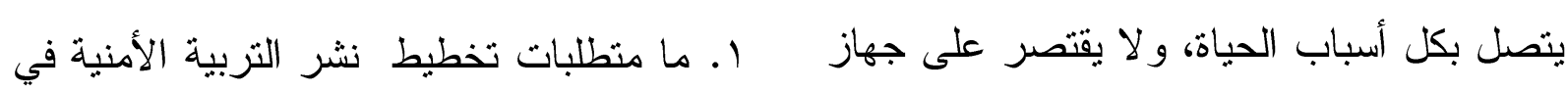

$$
\text { المؤسسات التربوية؟ }
$$

r. ما المرتكزات العلمية التي بني عليها مقترح تخطيط نشر النزبية الأمنية في المؤسسات

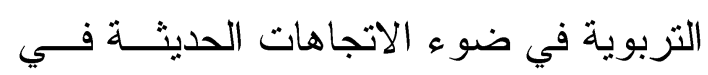

$$
\text { بناء المناهج? }
$$

ب. ما دور المؤسسات التزبوية المطلــوب فــي

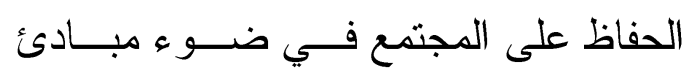

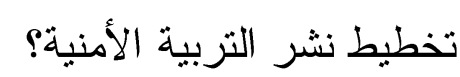

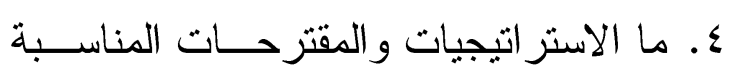

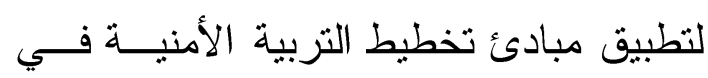

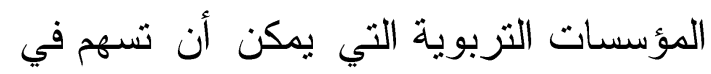

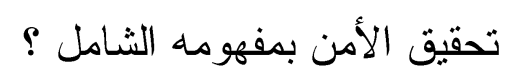

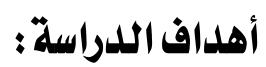

تهدف الدراسة الحالية إلى اقتراح نموذج

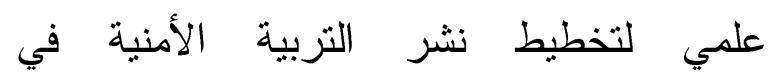
المؤسسات التربوية يُبنى على ما يلي: ا. التعرف إلى منطلبات تخطيط نشر التربية

$$
\text { الأمنية في المؤسسات التربوية. }
$$

r. وضع الأسس العلمية و المرتكزات التنظيمية

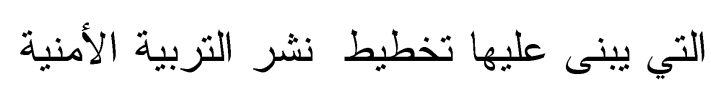

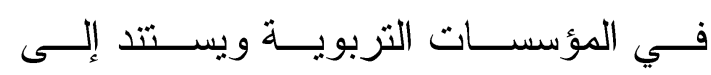
الاتجاهات الحديثة في بناء المنهج. r. إبراز دور المؤسسات التربوية في الحفاظ لأهاه على المجتمع في ضوء مبادئ تخطيط نشر التربية الأمنية.

ع. طرح بعض الاستراتيجيات و المقترحات المناسبة لتفعيل تخطيط التربية الأمنية في ولئين

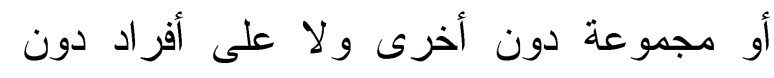
آخرين، بل هو مسؤولية الأمة جمعاء (الحوشان، لونان

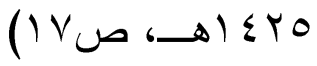
ومن هنا يمكن القول أن صياغة مشكلة الدراسة تتبع من الحاجة الملحة للتربية الأمنية

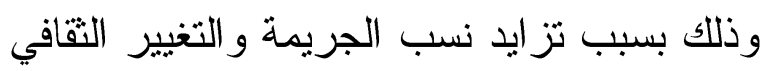

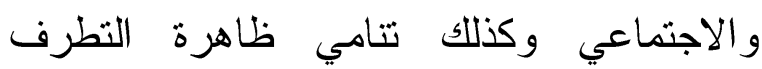
و الإرهاب ، وازدياد ظاهرة تعاطي المخدرات

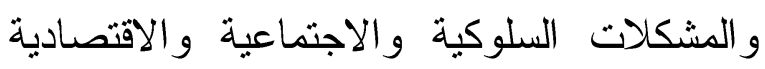
المصاحبة لها، وثثرة المعلومات والاتصالات كوتغير التركيبة السكانية ، وأهمية تكوين العلاقة وتؤة بين المؤسسات التربوية والأمنية وتكوين صورة ايجابيه للمؤسسة الامنية ،ولذا فإن هذه المرحلة تحتاج إلى تحديد الأهداف بدقة من أجل التخطيط

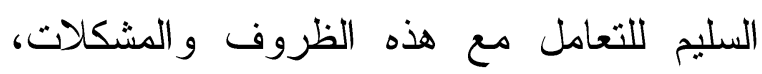

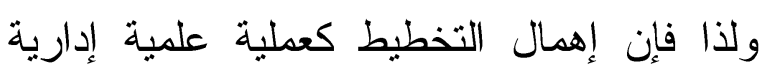
تُعنى بالتفكير المنظم الذي يسبق عملية التتفيذ في إليال

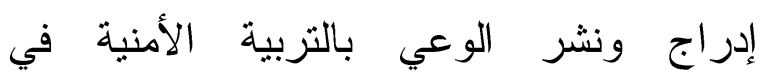

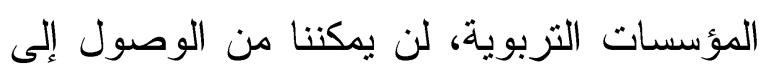

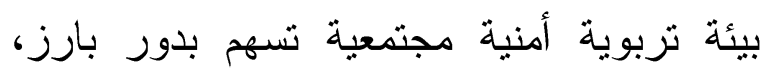

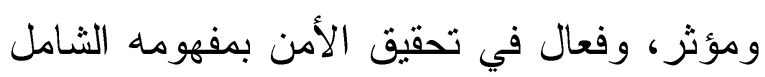
في المملكة العربية السعودية وغير ها من الدول العربية وغير العربية. وفي ضوء ذللك فقد برزت مشكلة البحث في السؤ ال التالي: - الت ضوء ما المقترح العلمي لتخطيط نثر التربية الأمنية في المؤسسات التربوية؟ 
0-من المؤمل أن يُستفاد من نتائج هذه الدراسة في تطوير العلاقات التكاملية بين المؤسسات التربوية و المؤسسات الأمنية.

ب-يُؤَّل أن تسهم الدراسة في تشجيع باحثين

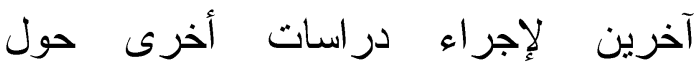
موضوع تخطيط وتتظيم نشر الثقافة و التربية الأمنية وتطبيقاتها التربوية.

مصطلحات الدراسة :

التخطيط : هو إثبات لفكرة ما بالرسم أو الكتابة وجعلها تدل دلالة تامة علي ما يقصد فِ الصورة والرسم وهو أيضاً التسطير والتهذيب والطريقة وِِّ المثل يقال جاء فلان وِّْ رأسه خطة: "أي أمر قد عزم عليه" . (ابن منظور،بr..r ص ص (1) (1). (1) والتخطيط عموماً هو " جهد فكري منظم ومستمر لاختيار أفضل الطرق لتحقيق أهداف

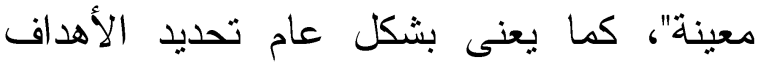
واستخدام أفضل الوسائل لتحقيقها بشكل علمي

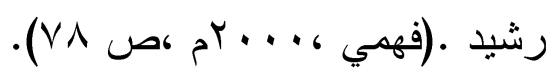

التربية جاء في لسان العرب : ربا الشئ أي زاد ونما واربيته أي نميته جاء في القرآن الكريم :قوله تعالى "يربي الصدقات" أي يزيدها وفي المعجم

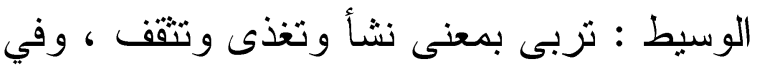

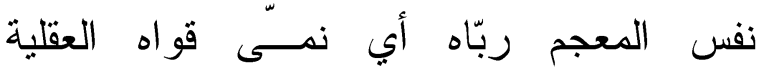
و الجسدية و الخلقية .

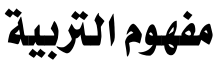

يرى (الرشدان وجعنيني r +. r م) أن التربية "مجموعة العمليات التي بها يستطيع المجتمع أن
المؤسسات التزبوية بهدف المساهمة في تحقيق الأمن بمفهومه الثامل .

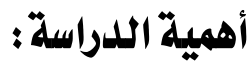

تتمثل أهمية الدراسة الحالية في أن الهاجس الأمني لم بعد مسؤولية رجال الأمن وحدهم وإنما أصبح الأمن قضية يجب أن تشارك فيها جميع مؤسسات المجتمع الرسمية وغير الرسمية وتمنل المؤسسات التزبوية الوسط الاجتماعي الثاني بعد الثدان الأسرة التي يتشرب فيها الناشئة القيم الاجتماعية و الثقافية في المجتمع و إذا ما فثلت المؤسسة التربوية في تشريب الناشئة تلك القيم فإن النيا المجتمع يفقد خط الدفاع الثاني ضد الجريمة. ويرى الباحث أن أهمية الدراسة يمكن اجمالها فيما يلي : 1-أهمية الموضوع الذي تناقشه حيث إن إن النية التخطيط لنشر التربية الأمنية في المؤسسات التربوية أصبح ضرورة علمية واجتماعبة و أمنية وسياسية ملحة. Y- المساهمة في إثراء الدراسات حول موضوع تخطيط نشر التربية الأمنية على مستوى المملكة العربية السعودية والعالم العربي. ب-يؤمل أن يسهم البحث في توضيح مفهوم التربية الأمنية وعلاقته بتطبيقات التربية الأمنية في المؤسسات التربوية. ع-يُتَّقَّع أن بستقيد في من نتائج هذه الدراسة كل

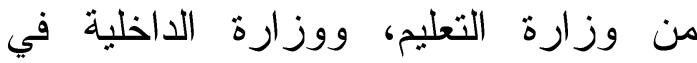
المملكة العربية السعودية و الدول العربية. 
مختلف المعلومات، والمعارف، و المهارات، والاتجاهات في ضوء محتوى المناهج، و المقررات، والنشاط المنهجي، و اللامنهجي وتكون الدراسة بها على مراحل ،وتتقسم المؤسسات التزبوية إلى مؤسسات تنربوية حكومية أو خاصة ولها نظام متكامل له وظائف رئيسة ، ووظائف أخرى محددة في إطار الحياة الاجتماعية في الدول العربية.

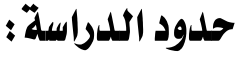

تم إعداد هذه الدراسة خلال الفصل الثاني في

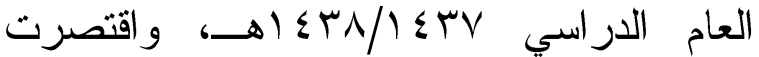
الدراسة في حدودها المكانية على التعليم في المالهان الوطن العربي ،كما تتناول الدراسة في حدودها الموضوعية على الكفاهيم التي تبناها البحث المتعلقة بتخطيط نشر التربية الأمنية ،والدور

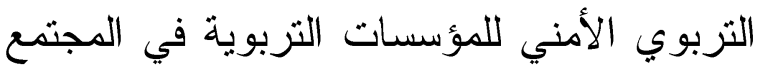
والأسس العلمية لتنظيم نشر الثقافة والتربية الأمنية في المؤسسات التربوية ، و ابراز التكامل بين المؤسسات التربوية و الأجهزة الأمنية.

\section{الاطار النظري}

\section{أولا :الاتجاهات الحليثة في بناء المناهج}

جاءت نظرية المنهج ووظائفهـــا الرئيســة

لتشكل إطارًا مرجعيًا يساعد أصـــاب القــــرار ومختلف التزبويين على أتخاذ الإجر اءات السليمة

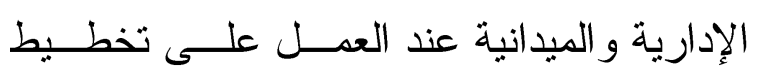
المناهج التعليمية و هندستها ، حيث تحدد الأسس علد الإنس الفلسفية و الاجتماعية و النفسية و المعرفية التـي لهي

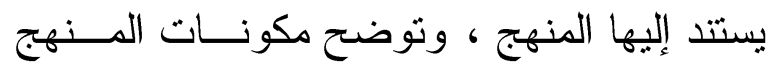

ينقل معارفه و أهدافه المكتسبة ليحافظ على بقائه، وتعني في الوقت نفسه التجدد المستمر لهذا التزاث و أيضـا للأفر اد الذين يحملونه، فهي عملية نمو وليست لها غاية إلا المزيد من النمو، إنها

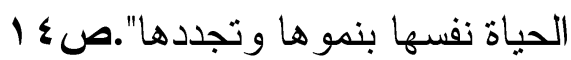
التربية الأمنية:

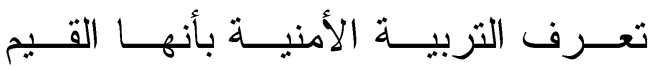

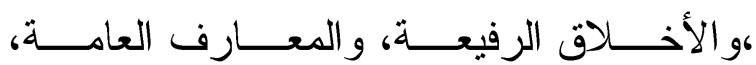
و المهار ات، و المعلومات الأمنية التي لها صــلـة التهاتل

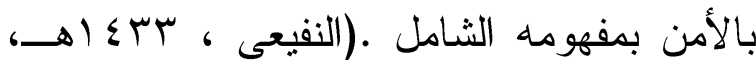

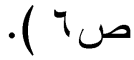

\section{ويعرفها الباحث إجرائيا في هذه الاراسة:} بأنها إثناعة الوعي بين كافة فئات المجتمع

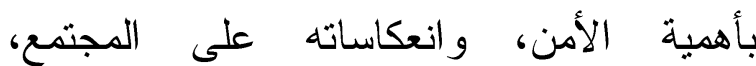
اجتماعباً، وسياسياً، و اقتصادياً ،كما أنها المبادئ العائ

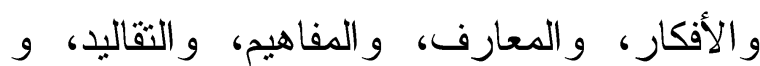

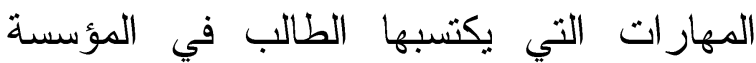
التربوية، و التي تمكنه من فهم الموقف الأمني، ومن ثم التفاعل مع معطياته، والتي تحدد ما

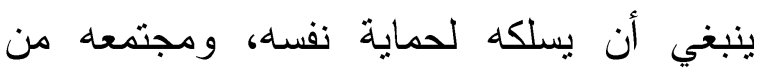
الخطر المحيط به.

\section{المؤسسات التربوية :}

المؤسسة التزبوية بناء اجتماعي يستمد مقوماته المؤسسبة من التكوين الاجتماعي العام، وتستمد منه هذه المؤسسة فلسفتها، وسياساتها،

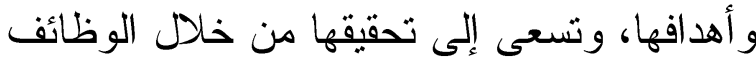

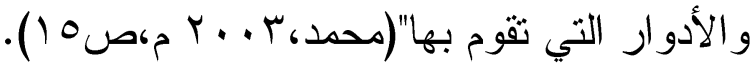
ويعرفها الباحث إجرائيا في هذه الاراسة: بأنها كل مؤسسة تربوية تعليمية يكتسب فيها الطلاب 
و الاختلافات بين هذه الاتجاهات يتركز في النظر إلى طبيعة التفاعل بين عناصر مدخلات المنهج وأبعاده ونــوع ع المخــرج التعليمـي أو النـــاتج

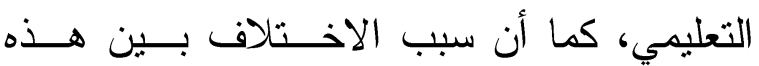
الاتجاهات برجع إلى طبيعة الفكر و الفلسفة التي يستتد عليها كل اتجاه، هذا من جانسـب، و إلــى لــ اختلاف النظرة لكل من: ( أ) طبيعة المتعلم.

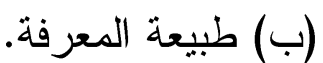
(ج) طبيعة المجتمع.

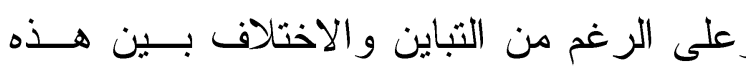
الاتجاهات ومن ثم نظريات المنهج، إلا أن هـــا الاختلاف قد يساهم في تطور الفكـر الإنســاني

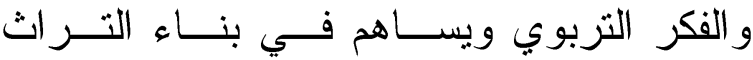

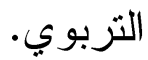

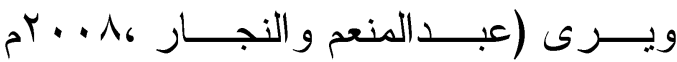

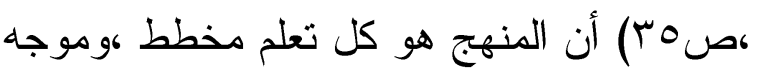

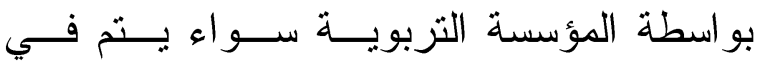
مجمو عات أو فرديا داخل المؤسسة الثربويـــة أو

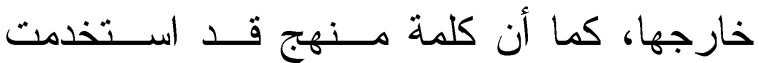
استخدامات عدة ، فالبعض نظر إليها على أنهـا خطة ، و البعض الآخر نظر إليها على أن المنهج وثيقة مكتوبة، و البعض ينظر إلى كلمــة مــــهج إثشارة إلى البرنامج التربوي و التعليمي، وهنــاك

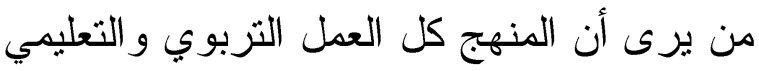

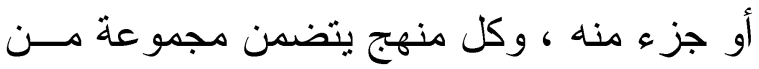

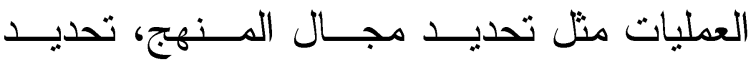
الأشخاص المشتركين في صنع المنهج، كتابــة المنهج، تتفيذ المنهج وتقويمه، ثم تطوير المنهج.
الرئيسة ، و العلاقة بين تلك المكونات ، وصو لا إلىى التز ابط و الآتساق .كما تبين خطوات بنــاء المنهج بدءًا من وضع الأهداف فاختيار المحتوى

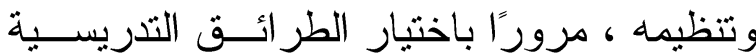
و الأنشطة التعليمية و الوسائل و التقنيات التعليمية، و انتهاء بالتقويم الذي يو اكب مختلف الخطــــوات السابقة ، ويتوجها بالتغذية الر اجعة.

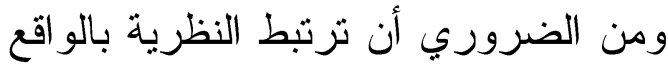

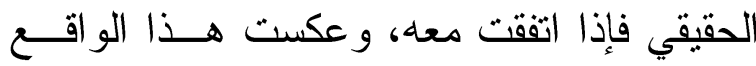
أصبح هذا دليلا على صدق النظرية و إذا ثبـــت عدم صحة ذلك فإن النظرية تصبح غير نافعة أو

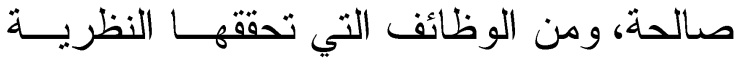

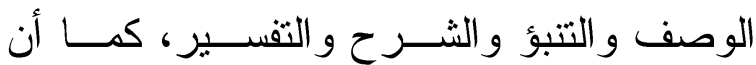
النظرية تقوم بوظيفة مهمة ألا وهـي مســـاعدة ولفئ الفرد في حل مشكلاته ولكن ينبغي في هــذا أن

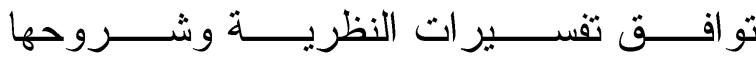

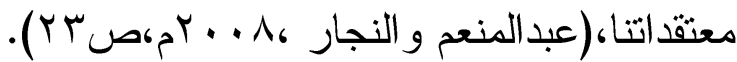
ويقصد بنظرية المــنهج مجموعــة مسن العلاقات المرتبطة التي تعبر عن المـــهج مـن حيث عناصره ،وتصميمه ،و استخدامه ،وتقويمه، وتطويره، وطبيعة العلاقات ، و التقاعلات بـين

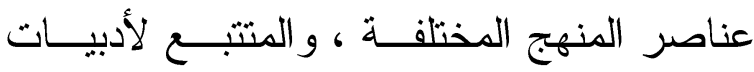
المناهج يجدها تدور حول اتجاهات ثلاثة (الهندي لهات الهات

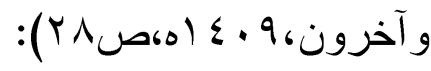

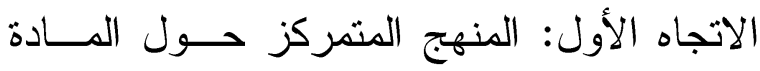

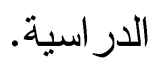
الاتجاه الثاني: المنهج المتمركز حول المتعلم. الاتجاه الثالث: المنهج المتمركز حول المجتمع. 


\section{ج_ تنظيمات المنهجج}

وتعتبر الفلسفة التربوية هي التي تحــدد وجهــة النظر للطبيعة الانسانية ومفهوم الفهر و أهــداف التربية ، ونظر أ لاخــتلاف طبيعــة ،وحاجــات

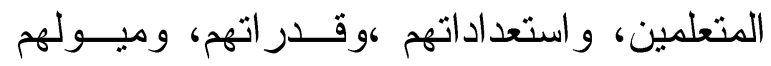
،ظهرت آراء تؤكد على ضرورة تتوع الخبرات التي ثقدم للمتعلمين ، وذلك بما يحقـق اثــــاع

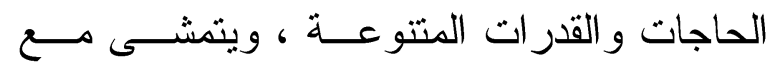
الاختلاف في ميول التلاميذ، كمــــا أن در اســة الواقع خاصة ما يتعلق بالمجتمع الــذي تشــتق

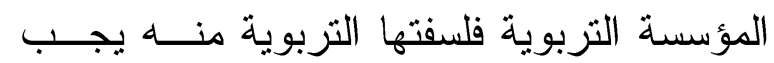
الاهتمام البالغ به، ومن هنا جاء التهــايز فـــي تتظيمات المنهج وقد حددتها بعض الدر اسات في تتظيمات اربعة (المكاوي، ابك (ه ، صج + (1): أولاً : منهج المواد المنفصلة : يضم المناهج التي تدور حول المقررات الدر اسية. ثانياً : منهج النشاط أو الخبرة : يضم المنـــاهج التي تدور حول ميول المتعلمين ونشاطهح • ثالثا : منهج الوحدات : يضم المناهج التي تبرز

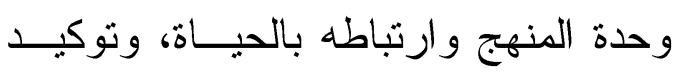

$$
\text { وحدة المعرفة. }
$$
رابعاً : المنهج المحوري : يضم المناهج التـي تدور حــول تتظـيم خبــرات المتعلمــين وحاجاتهم ومشكلاتهم المشتركة و المخطط

$$
\text { لها مسبقاً. }
$$

\section{دـــالعوامل الضرويةية لتخطبط المحتوى:} يعد تخطيط المحتوى والخبرات التعليمية عملية أساسية من عمليات بناء المنهج وتنظيمه ، مما يساعد في تحقيق الأهداف التربوية المــراد
ثانيا : تخطيط المناهج

أ- المفهوم:

تطور مفهوم تخطيط المنهج وتتظيمه في الوقت المعاصر فأصبح خطــوة يقـوم مــن خلالهــــا المختصـــون بوضـــع المو اصــفات و المعــايير التطويرية و التنفيذية العديدة التي تخص المــنهج ومكوناته ، ويستتد تطوير المناهج و المقــررات على مجموعة من الاسس كالتخطيط الذي بشمل ترتيب الأولويات ، ودر اسة الو اقع و الامكانــات

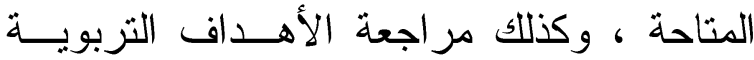
و التعليميـــة وربطهــــا بمتطلبــــات المجتمـــعـ ،

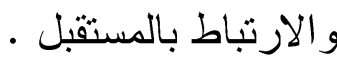
ب- الخطوات : بات

تمر أي عملية تطــوير للمنـــاهج و المقــررات بمجموعة من الخطوات التـي تســتند لمفهــوم

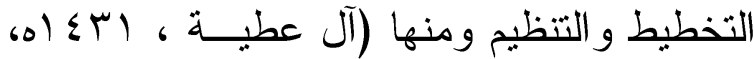

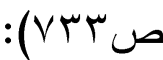
1 - الاستتاد الى فلسفة تزبوية تعليمية و اضحة . r- بر اسة الو اقع الحالي وتقويمه . r-تحديد مستوى التغيير و التطوير • צ-وضع خطط عمل تتفيذية . ه-تخطيط المنهج المر اد تطويره وبنائه . ج-تهيئة البيئة التزبوية و التعليمية لاستقباله .

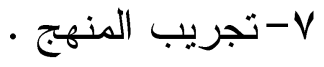
- 1-تعميم المنهج وتتفيذه . 9- التقييم و التقـــويم و الاســتهادة مـــن التخذيـــة

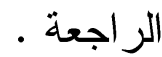


التقافة و التربية الأمنية تتعلق بوضع الاطـــار

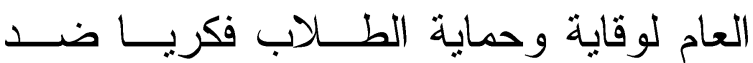
الانحر افات و المخاطر الأمنية باتخاذ جميــع التدابير المادية و المعنوية من قبل المؤسســة التربوية بالأساليب التزبوية الإسلامية التـي تضمن لهم حياة مطمئنــة ومســتقرة أمنيً وبالنالي عقائدياً و نفسياً و اجتماعياً و اقتصادياً

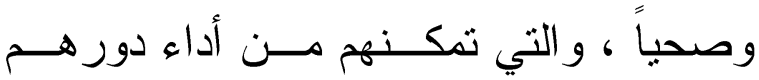

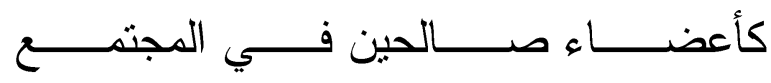

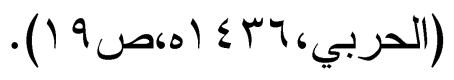
ويرى الباحث أن التربية الأمنيــة هـــي الاطلار العام لحماية المجتمع، وصبانة أمنـــه، ومقدر اته الوطنية من خلال المؤسسة التربوية حيث يتم تتفيذ بر امج التربية الأمنية ، و التي تهدف إلى تشكيل النشء لـــــا فيــه صـــالح المجنمع، و إعداد جيل واع، ومحصن أمنياً ور اسخ أخلاقياً بستطيع أن بميز بين النــافع و الضار ، ويتعامل بفهم ووعي مع منطلبــات العصر ، ومستحدثانه، ويستفيد من إيجابياتها، ويعرض عن سلبياتها من خلال رقابته الذاتية

وقناعته الثخصية.

\section{بـــالمبادئ العامة للتربية الأمنية}

تتمثل المبادئ العامة للتربية الأمنية في عديد من النقاط، نعرضها بعض منها فيما يلي(فهـــي

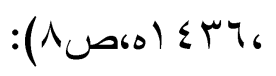

تحقيقها ، ولذلك فإن هناك عدد من العو امل يجب مر اعاتها عنــد تخطــيط المحتــوى (الهنــدي

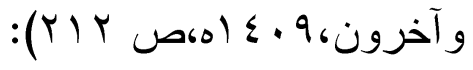

1- اختبار المحتوى في ضوء المعايير مرتبطة بالأهداف و الو اقع وحاجات المتعلمين . r- مر اعـــاة الخبــرات الســـابقة للمتعلمــين

$$
\text { وتنو عها. }
$$

ب- مر اعاة الاستمر ارية والتكامــل و التتـــابع، و التوازن في تتظيم المحتوى.

ع- استخدام بيئة تعليميــة وطــرق ووســـئل تدريس مناسبة وفاعلة .

\section{ثالثا : التزبية الأمنية}

$$
\text { أ- المفهوم : }
$$

في زمن كالذي نحن فيه ما أحوجنا إلى التزبيــة الأمنية المنبثقة من روح الإسلام وتعاليمه ، و لأن

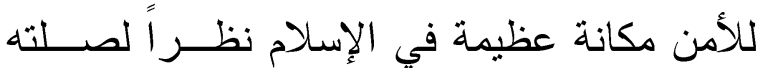
المباشرة بحياة الناس وســلامتهم و اســثقر ار هم على جميع المستويات، لذا فإن إعـــداد وتربيــة الأجيال بشكل يفي بمنطلبات التربيــة الأمنيــة

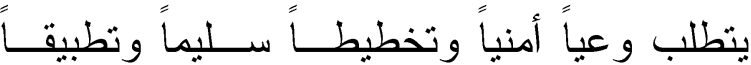
و اضحاً، ومن هنا فإن المؤسسات التربوية لهــا دور بارز في تحقيق ذلك من خــلال مناهجهـا

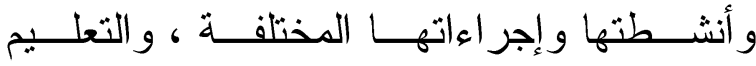
كمنظومة منكاملة يعمق الهوية ويغرس الانتماء و الو لاء للوطن ثم للأمة الإسلامية، ونستطيع من خلاله أن نحافظ به على هويتتا وفي الوقت نفسه المحافظة على أمن المجتمع . ويعتبر كثير من الباحثين أن الثقافة الأمنية جزء دن التربية الأمنية ،ويمكن القول بـأن 
ا. ـ تتمية الثقافة و التربية الأمنية لاى الطــلاب

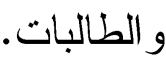

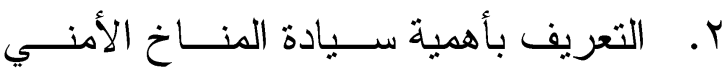
الإيجابي و أثره في تطور المجتمع.

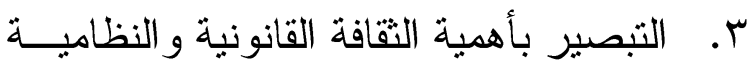
كي يعرف المو اطن حقوقه وو اجباته

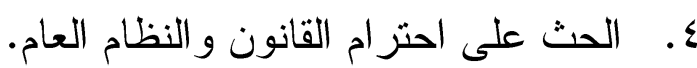

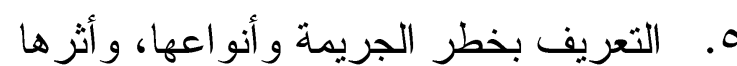
على الفرد و المجتمع. T. مكافحة الجريمة، و الوقاية من الانحر اف. V. تحقيق الأمن الوقائي لمواجهة الجريمة.

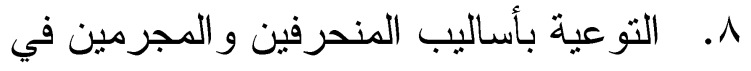
ارتكاب الجر ائم المختلفة.

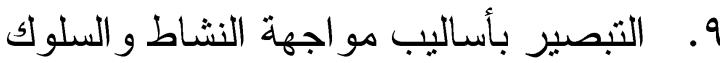
الإجر امي. • اـ تعزيز مفهوم الثرطة المجتمعية وأن الأمن

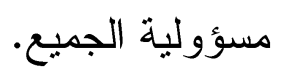
11 ـ الحث على الإبلاغ عن الجر ائم المختلفــة، وتقديم المعلومات التي تساعد أجهزة الأمن

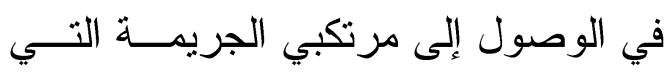
تهدد أمن الوطن و المو اطن.

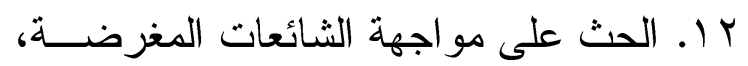
و الإبلاغ عن مروجيها. سا ا. إز الة الحاجز النفسي بــين رجــــ الأمــن و المو اطن. ـ ا ـ تتمية التقة و التفاهم و الاحتر ام المتبادل بين رجال الأمن و المو اطنين.

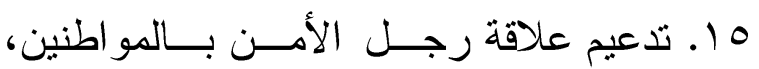
وتحسين صورة الشرطة لدى المو اطنين.
ا. تربية المو اطن وتتشئته تتشــئة إبــلامية قويمة، وفق المقومات و القيم التي تتضمنها العقيدة الإسلامية. r. ت تعزيز الانتماء الوطني و الهوية الوطنية.

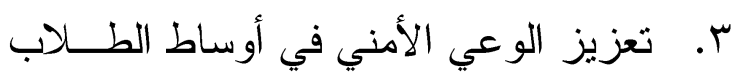

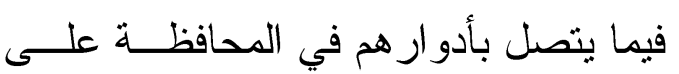

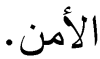
ع. ترسيخ مبدأ المسؤولية المجتمعية.

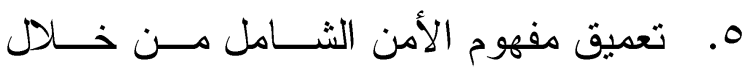
تأصيل الانتماء و الو لاء و المسؤولية. T. تعزيز الوعي الثرعي الصحيح بين أفراد

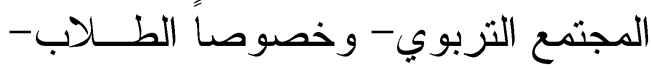
فيما يتعلق بقضايا الغلو و التكفير و التطرف ونداف

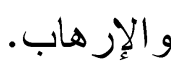
V. حماية الأحداث و الثباب من الوقــوع فــي

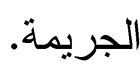
^. غرس المهار ات و القيم الإيجابية للتفاعل مع

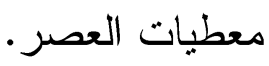
9 9. إكساب الفرد مهار ات التفكير الموضـــوعي

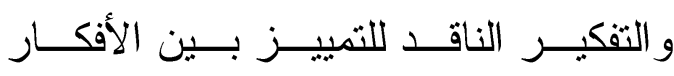
الصحيحة و الأفكار الخاطئة. • ا. التو عية بأخطار تعاطي المخدرات، و أثار ها

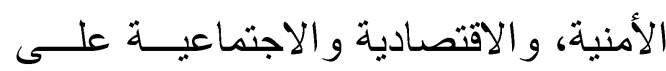
الفرد و المجتمع.

\section{جـــالأهداف التطبيقية المباشرة التربية الأمنية}

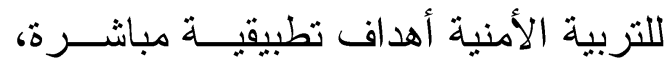

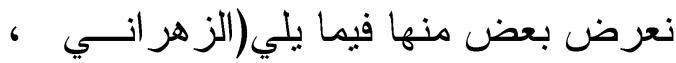

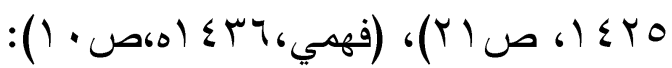


السعودي إلى المدن الكبرى، وتحول بنيان

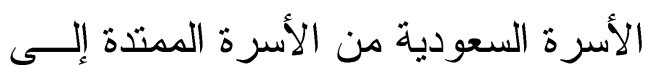
الأسر الصغيرة، وقد أدت هذه التغيــر ات السريعة إلى ظهور عدد مــن المشــكلات الاجتماعية منتل ضعف التماسك الأســري وقلة الروابط الاجتماعية، مما أثر بالتــالي في ضعف الضو ابط الاجتماعية الداخليــة غير الرسمية، وتعاظمت الحاجة إلى تطوير مهام جهات الضبط الرسمية بما في ذلـــك قطاعات أجززة الأمن المختلفة. خ- تكوين صورة إيجابية عن القطاعات الأمنية

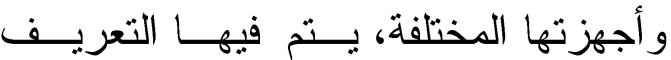
بجهود الأجهزة الأمنية ودور هم في خدمــة

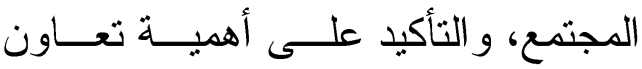
المو اطن وتفهمه لجهود الأجهزة الأمنية.

\section{الدراسات السيابقة:}

هدفت دراسة الحربي (آبـ اهـ) الى معرفــة المبرر ات التي تفرض تحقبــق التكامــل بــين الأجهزة الأمنية و المؤسسات التربوية ، و تحديد متطلبات تحقيق التكامل بين الأجهــزة الأمنيـــة و المؤسسات التربويــة ، و إعـــداد اســتر اتيجية مقترحة لتحقيق التكامل بين الأجهــزة الأمنيــة

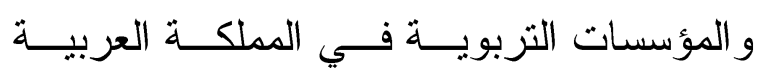
السعودية، كما وخلصت نتائج الدر اسة إلــى أنّ المبرر ات التي تفرض تحقبــق التكامــلـ بــين الأجهزة الأمنية و المؤسسات التربوية في المملكة

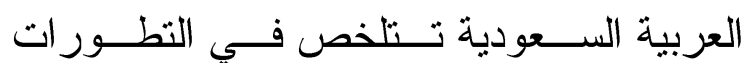
و التحديات الأمنيــة و السياســـية و الاجتماعيــة

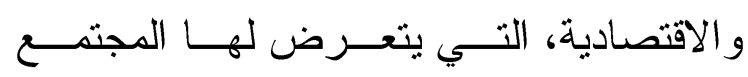

دـ دواعي تطبيق التربية الأمنية في المؤسسات التربوية:

أدت جملـــة مـــن العوامــلـ السياســـية و الاقتصادية و الاجتماعية و السكانية و الأمنية إلى تتامي الحاجة إلى تطبيق التربية الأمنيــة فـــي المؤسسات التربوية السعودية، ويأتي في مقدمـــة

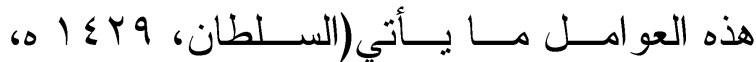

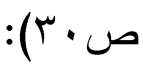
أ- تز ايد نسب الجريمة.

ب- التغير ات الثقافية و الاجتماعيــة العديـــدة، و التي لم يكن كثير منها موجود من قبـلـل، و التي منها: تغيــر الأنمـــاط و العلاقـــات الاجتماعية على مستوى الجــو ار و الحــي والأسرة، وظهور النزوع إلى الاســتقلالية و الفردية، وتز اجع مظاهر الضــبط غيــر الرسمي (العرف، التقاليد، العادات، القــيم الروحية، و غير ذلك). ت- تتامي ظاهرة التطرف و الإزهاب.

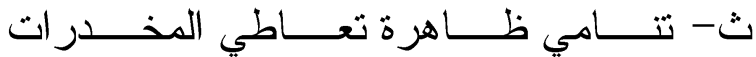

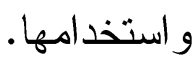

ج- التقدم الرهيــب فــي ثــورة المعلومـــات و الاتصالات، و التكنولوجيا. ح- التغير ات السريعة في البنية السكانية، ففـي المملكة العربية السعودية - علـى ســبيل المثال - قادت حركة التنمية الاقتصــادية، من خلال مئات المشاريع العملاقـــة إلــى الاستعانة بالملايين من العمالة الو افدة مــن مختلـــف أنحــــاء العـــالم، و أدت الــــوفرة الاقتصادية إلى الهجرة من القرى والريف 
وقد هدفت دراسة الثاعر (عباع اه) إلي وضع نموذج لخطة منهجية لعناصر الثقافة

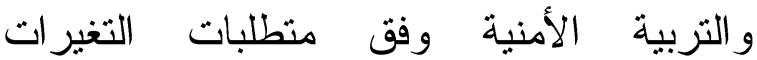
المعاصرة، وتحقيق التوازن العلمي و الموضوعي لتحقيق أهداف الثقافة والتربية الأمنية من خلال وسائل اتصال متميزة ، وتوحيد الجهود في مجال الثقافة والتربية الأمنية والتركيز على المخرجات ، وتوصلت إلى وضع متطلبات إعداد الثقافة و التربية الأمنية ونشرها، ومبررات النموذج، وتقييم برنامج التقافة والتربية الأمنية، كما أوصت الدراسة بأن يؤخذ سلوك الفرد و العامل النفسي و الدو افع ومر احل الادر اك بعين

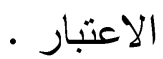

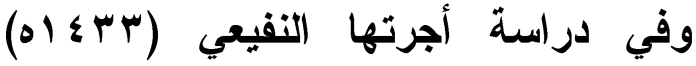
هدفت هذه الدراسة إلى التعرف على دور الإدارة المدرسية في تتمية الثقافة و التربية الأمنية لدى طلاب المرحلة الثانوية بمحافظة الطائف من لنان خلا أربعة محاور و هي: دور الإدارة المدرسية في تتمية التقافة والتربية الأمنية

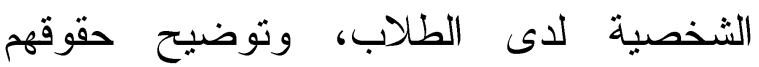
وواجباتهر ، وتتمية ثقافتهر الأمنية المتعلقة بالأمن الفكري، وتتمية الثقافة و التربية الأمنية المتعلقة بأمن و سلامة الوطن لدى الطلاب ، ومن أهم النتائج التي توصلت لها الدراسة أن لنال دور الإدارة المدرسية في تتمية الثقافة والتربية الأمنية لدى طلاب المرحلة الثانوية كانت بصفة

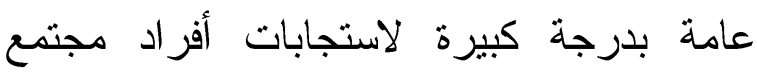
الدر اسة لجميع محاور الدراسة .
اللـــعودي. و التحـــــلات العقديــة و الفكريـــة ، وتأثير ات العولمة وتطـــور وســائل الاتصـــال و الإعلام. و القصور الواضح في التو اصل بــين الأجهزة الأمنية، والمؤسسات التزبوية، و والتأثير القوي للمؤسسات التربوية في أفراد المجتـــع. وحاجة

الأجهزة الأمنية للتعاون مع المؤسسات التزبوية لمواجهة بعض الظــــواهر الســلوكية و الفكريــــة و الوقاية منها، وثقة المجتمع في الأجهزة الأمنية، و المؤسسات التربوية .

كماهدفت دراسة فهي (هب ـ اه) الى التعرف إلى الدور التزبوي الأمني للجامعات و أعضـــاء

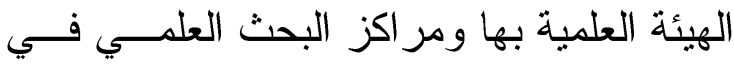

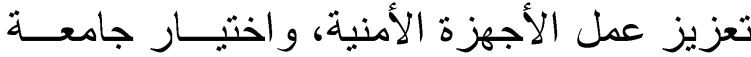

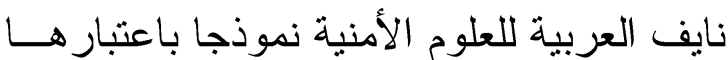

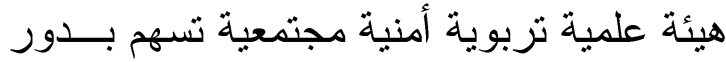
بارز ومؤثر وفعال في تحقيق التعاون و التكامل وتعزيز عمل الأجهزة الأمنية المختلفة بالمملكـــة

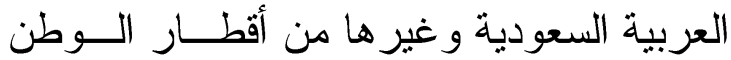
العربي وغير العربي.

ومن أهم نتائجها تحديد الدور التربوي الأمنــي

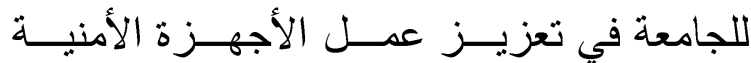

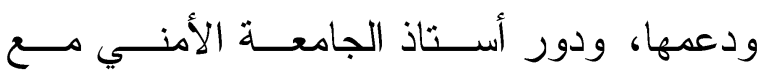
مؤسسات المجتمع الذي يسهم في تعزيز عهــل ودلـ

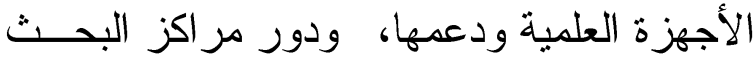
العلمي وما مسئوليتها فــي إجــر اء الدراســات الأمنية التي تعزز عمل الأجهزة الأمنية، و كيفية تحقيق التكامل بين الجامعات و الأجهزة الأمنية. 


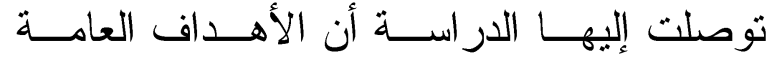

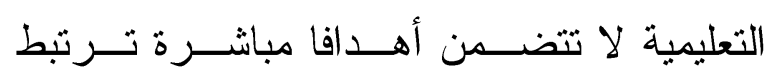
بالتو عية الأمنية وأبعادها المختلفة ، وأن الأنشطة الصفية ارتبطت بمحتوى المقرر ات و المناهج ولم يظهر الترابط بينها وبين أبعاد التوعية الأمنيــة

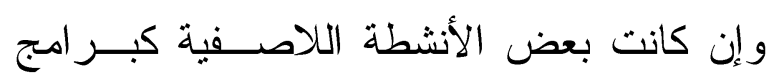

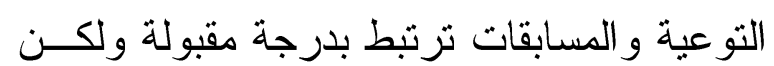
بنقصها الجدية و النظام ل

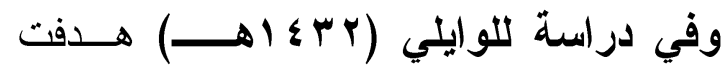
لاستكشاف جو انب التوعية الأمنية فـي خطـ لـ وبر امج التعليم العام وتحديد معوقاتها، ورصــد هـ

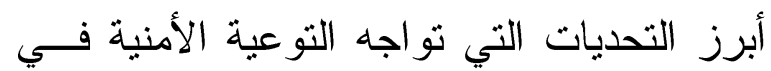
التعليم العام، ومن أهم النتائج التي توصلت إليها الدراسة أن عدم فهم الخصائص العمرية يشــــل عائقاً من معوقات تحقيق أهداف التوعية الأمنية، وأن التوعية الأمنية في المؤسســات التربويــة الثانوية عن طريث برامج التوعية ساهمت بشكل أو بآخر في تصحيح بعض المفاهيم المغلوطة في مجال الأمن الفكري والانحر اف ، وقد أوصـــ بـت الدر اسة بضرورة وضـــع خطـــ اســتر اتيجية

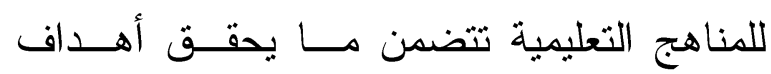
التوعية الأمنية وضورة توفير إمكانات مادية في البيئة المدرسية وخاصة التقنية لتعزيـز نشــر التوعية الأمنية .

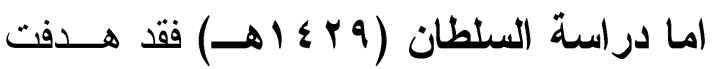
إلىى وضنع الأهداف التي تسعى التربية الأمنيــة لتحقيقها ومعرفة المعوقات التي قد نو اجه تطبيق التربية الأمنية ،ودو اعي تطبيق التربية الأمنيــة

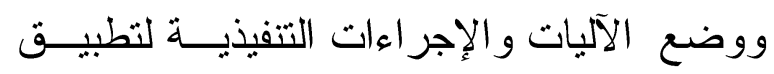

كما هدفت دراسة عابد والمري (r (ه اه) إلى وضع المبررات العلمية والعملية لتخطيط وبناء مصفوفة منهج التوعية الأمنية وتحديد الخصائص الذاتية لها ، ومقوماتها الرئيسة ، و المفاهيم المرتبطة بها في إطار الواقع المعاصر، وبناء محتو اها في ضوء على أساس إه من القيم الإسلامية والانتماء، ومن أهم النتائج التي توصلت لها الدراسة أن المكونات المعرفية للتوعية الأمنية المعتمدة حاليا في مناهج التعليم العام قد خلت من المنهجية في إعدادها وكذلك أساليب ووسائل تقديمها ومتابعة نواتجها في ظل عدم اخضاعها لمعايير القياس التزبوية الأمر الذي حال بينها وبين تحقيق الأهداف التي أعدت من أجلها .

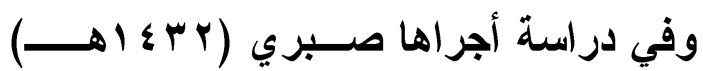
هدفت لتحديد أهم مجالات التوعية الأمنية التـي ينبني لمحتوى المناهج المطورة بمراحل التعليم العام في المملكة العربية السعودية أن تتضمنها،

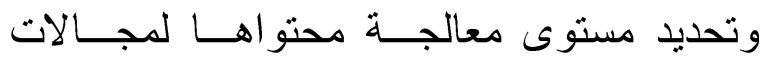

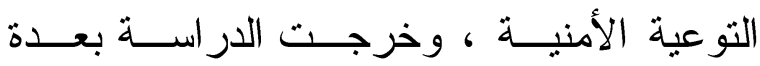
توصيات من أبرزها ضرورة إجراء مزيد مسن وهن الدراسات و البحوث لكيفية وتضـــين التوعيــة

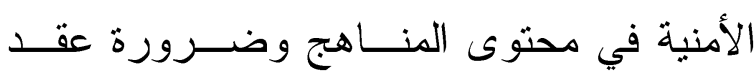

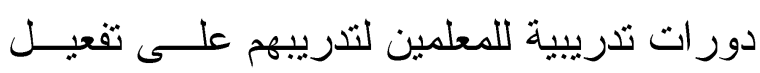
خبرات التو عية الأمنية .

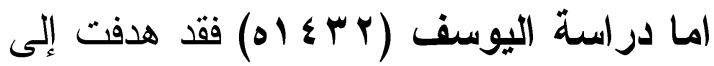
تشخيص واقع التوعية الأمنية في مناهج التعليم العام ، وتقييم عناصر المنهج في ضــوء أبعــاد التوعية الأمنية و أهدافها ، ومن أهم النتائج التي 
متطلبات تخطيط التربية الأمنية:

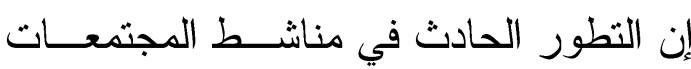

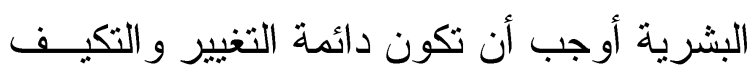
المستمر مع معطبات العصر الثقنية، لذلك كـــان الإنسان و لا يز ال دائم التطلع إلى مو اكبة عملية التقدم العلمي و الإفادة منه، ورغم ما لهذا التطلع

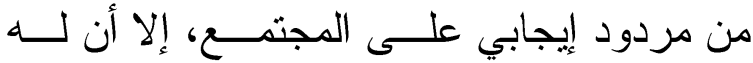

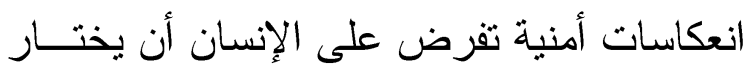

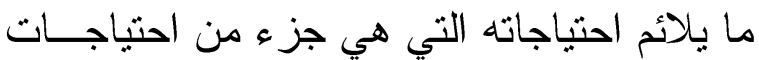
مجتمعه دون أن يؤثر ذلك في القـيم و المفــــــيم و الأعر اف الاجتماعية، وثقافة الأمة هو تر اثهــا دئ الحضاري و الفكري بحيث تشكل ثقافــة الأمسـة

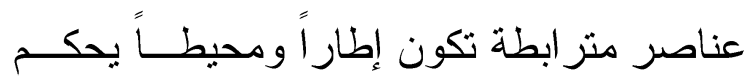
الأفر اد و المجتمع. ومن صفات التزبية الأمنية أنها في تغير مستمر، ويرجع هذا التغيير إلى تقبل أفراد الادئه

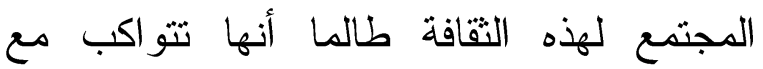
رغبتهم في التغير، وتسعى النزبية الأمنية لتحقيق تلك الرغبة و إلى رقي الفكر وسمو الوجدان عن طريق طرح عناصر ثقافية أمنية مفعمة بالتجارب و المعارف، وكل هذا من شأنه

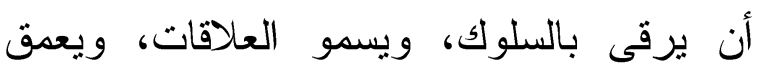
الانتماء الوطني، ويؤكد الإحساس بالوحدة

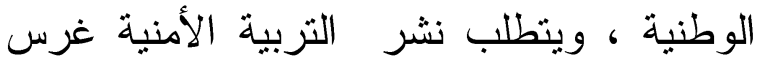

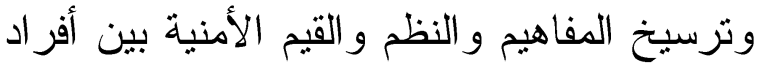

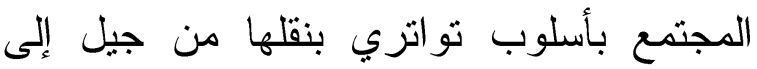
جيل، نموذج عبارة عن مخطط وظيفته تجسيد ونشر مفردات التربية الأمنية وظيفته البناء الفاعل للمفاهيم و القيم و النظم ويوجه العمل ويقدم
التربية الأمنية ، ومن أهم النتائج التي توصلت اليها الدراسة إقامة لجان وفرق عمل مشــتركة

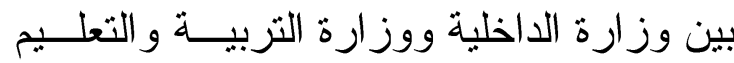
لتخطيط البرامج و الأنشطة و الفعاليات اللازمـــة ولنة

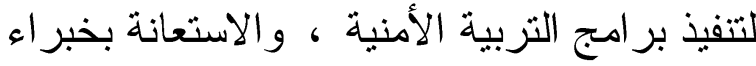
متخصصين في مجالات التربية و الاجتماع وعلم النفس و الثريعة الإسلامية لتطوير بر امج التربية

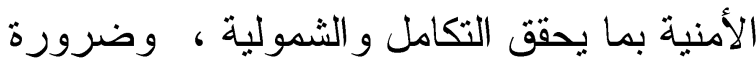

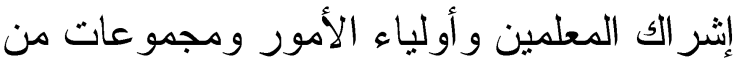
الطلاب في تطوير برامج التربية الأمنية.

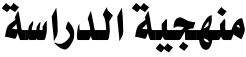

حيث إن الدراسة الحالية ارتبطت بتوضــيح ووصف المشكلة المبنية على كيفية نشر الثقافــة

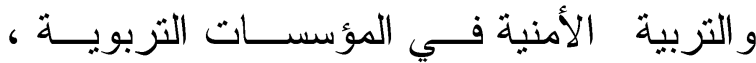
وتتاولتها بالتحليل و التفسير بغرض الوصول إلى

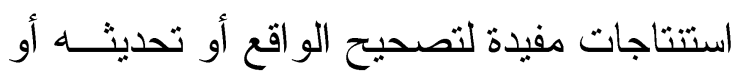
استكماله أو استحداث معرفة جديدة ، فقد استخدم الباحث منهج البحث الوصفي الوثـائقي و الــــي يعني الجمع المتأني و الاققيق للوثائق المتــــوافرة عن مشكلة البحث ومن ثم القيام بتحليلها تحلــــلا يستطيع الباحث بموجبه اســتنتاج مــا يتصـل لــل بمشكلة البحث ( العساف ، · ( • بو، ص1/1) . تتائج الدراسة : للإجابة عن سؤال الاراسة الأول والذي نصه " ما متطلبات تخطيط نشر الثثافة والتربية الأمنية

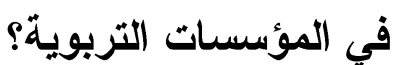




\section{دور التخطيط والتنظيم في نشر التربية الأمنية}

يعد التخطبط السليم عامل أساسي في توليد المعرفة، حبث ينبغي أن يكون لبرنامج التربية

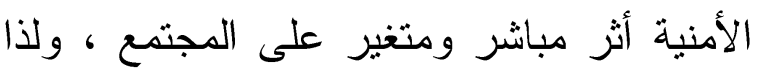

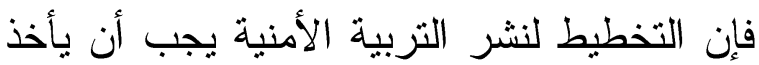
بالاعتبار سيكلوجية الفرد وخصائصه ، و لابد من العودة إلى نظريات التعلم، حيث إن التعلم هو اكتساب السلوك من خلال ما يتلقاه الفرد من معلومات وخبرات وتجارب تؤدي إلى استجابة

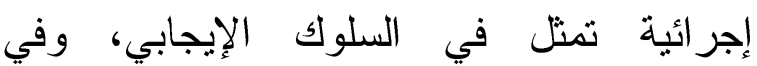
مضمونات علم النفس التربوي، فإن الحاجات النفسية تعد الحافز الرئيس في اكتساب السلوك، لذا نلحظ أن من مقومات اكتساب النقافة و التربية الأمنية إعادة تثكيل أنماط السلوك الاستجابي، فالفرد و البيئة من مقومات إحداث الأثر السلوكي، فهنالك كم من العوامل السلوكية تتثكل نتيجة للخصائص الفردية ، فالفرد يتعلم استجابات جديدة في موقف اجتماعي معين، فالتربية الأمنية التي يرجى أن تكون سلوكاً استجابياً إيجابيا هي مجموعة من الفعاليات المثيرة لتلك الإجراءات على شكل معارف ومهار ات و اتجاهات مستمدة من المعرفة على بيانات فكرية وسلوكية مرتبطة بمعايير المتغير ات العصرية ومضامينها مثل: 1-عرض الأفكار الرئيسة التي تدل على

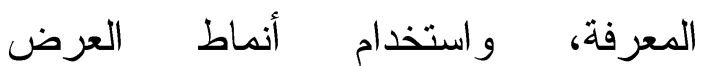
الموضوعي المتز امن مع المتغيرات.

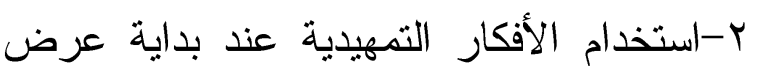
المعلومات وذللك كإستراتيجية لمعالجة
الحلول للمشكلات و الظواهر الأمنية ودراسة العوامل المؤثرة فيه و العلاقات بين أجزائه و أبعاده بمعنى أنه وصف لإجر اءات وعمليات تتطلبها التزبية الأمنية، ووصف لأنشطة ومشاريع تتكامل وتتتاغم لتقديم برنامج منهجي منظم يشيع حاجات أمنية إنسانية موظفاً مفهوم نظرية التعليم الاجتماعي التي من مضامينها ما

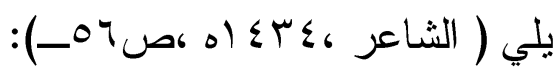

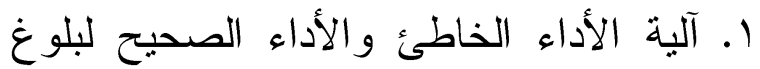
تعديل السلوك. r. التفاعل الاجتماعي مع الآخرين في بيئة غنية بالمعاني و القير. r. صياغة للمفاهيم و القيم بأسلوب لفظي ولفي مصحوب بنشاط غير لفظي لبلوغ التفكير

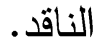
ع. -توظيف رؤية "بلوم" لمستويات المعرفة و الاعتماد عليها في التّرج اللفظي لمفردات

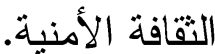
ه. عرض نماذج سلوكية لتعزيز التفكير المقارن للوصول إلى تنظيم السلوك المرغوب. T. التو افق بين القيم السائدة و المحددات الثقافية و الاجتماعية والدينية و الأخلاقية من خلا

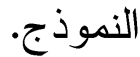
V. تحديد الأنماط السلوكية في المجتمح، و التوقعات المرتبطة بها، والآثار المترتبة عليها، واختبار النماذج السلوكية المراد نشر ها من خلال الثقافة الأمنية. 
r. الكفايات المطلوبة في العمل الأمني. r. التو اصل في منظومة السلوك المهني الأمني.

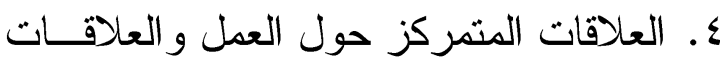
المتمركزة حول الثخص.

0. سيكولوجية الجماهير و الضبط الاجتماعي. T. دور المؤسسات التربوية والاجتماعية. V. التغير ات المعرفية و الانحر اف الفكري. ه. البعد الوطني و البعد الدولي للأمن. 9. البعد الاجتماعي و البعد الاقتصادي للأمن. ومن المهم عند التخطيط السليم لنشر التربية

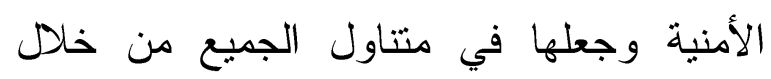

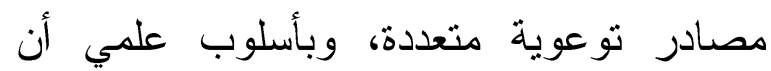

$$
\text { يراعي : الاع: }
$$

أولا: تتمية الاتجاه نحو المجتمع والمواطن

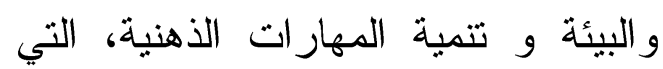

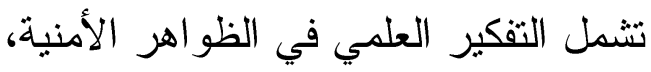

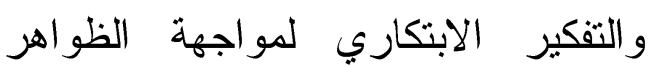

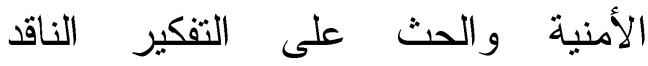

$$
\text { للممارسات الأمنية. }
$$

ثانيا : الإعداد لنشر التربية الأمنية، ويشمل:

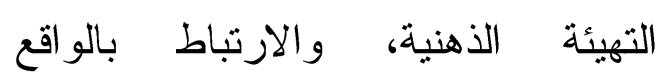

$$
\text { و المو اعمة العمرية و المكانية. }
$$

ثالثا: التوازن العلمي و الموضوعي لتحقيق أهداف التربية الأمنية في ضون ضون منطلبات التغيرات المعاصرة كسرد الحقائق و المفاهيم و القبم و الممارسات

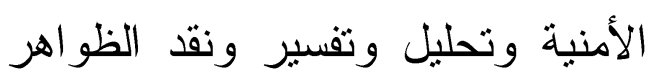

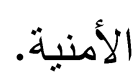

القصور الثقافي الذي يعوق التدرج في

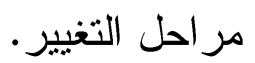
r- انتقاء مفردات التربية الأمنية ومكونات خطة الإعداد و انتقاء المعارف و المهارات و المعلومات وفق أسلوب النظم. ـ - تسكين المهار ات و المعارف و الاتجاهات في ولي

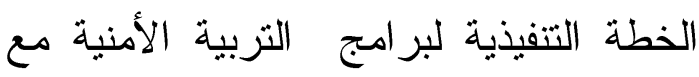
مر اعاة العلاقة الموضوعية والوظيفية لكل عنصر من عناصر الثربية الأمنية.

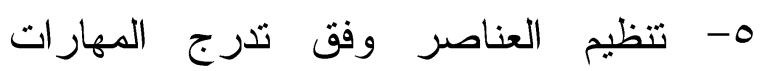

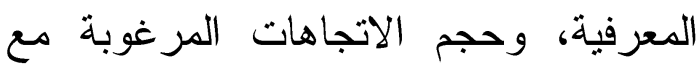
التأكيد على الأسس العلمية و المنهجية. ولتحقيق كفاءة نشر التربية الأمنية بالصورة الصنية

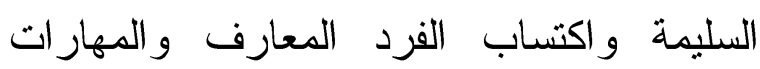
والاتجاهات وفق الإجراءات سالفة الذكر الذي ولي

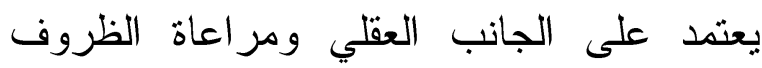
النفسية، مثل الثقبل و الدافعية و الذكاء و الإدراك الك

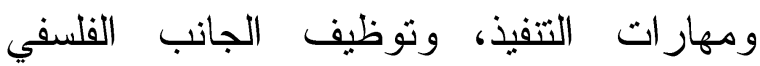
للمفاهيم الداعي إلى تسلسل الأفكار وتبسيطها

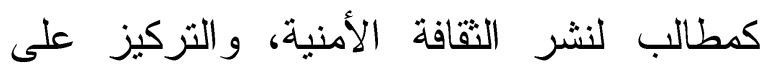
الجانب المعرفي ، إضافة إلى الجو انب الوجدانية

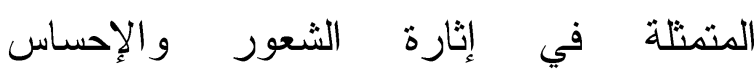
و الانطباعات و الانتماء للمجتمع و الوطن و وغرس ولته • القيم ويرى الباحث في ضوء ما تقدم وفي ظل هذا التوجه العلمي أن نشر التربية الأمنية يتطلب مر اعاة المحاور و الأبعاد و العناصر التالية:

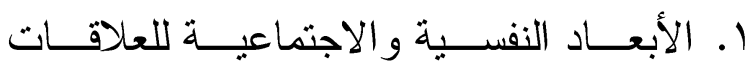


إعداد المتعلمين لمواجهة تلك المشكلات و اقتر اح

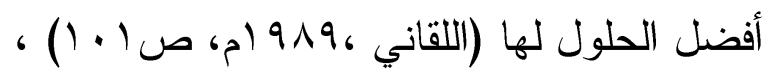
و هذه الدراسة تسعى إلى وضع تصور لتنظيم نشر التربية الأمنية في المؤسسات التربورية

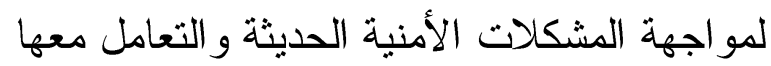
وفقا لبعض المرتكزات العلمية التي يمكن

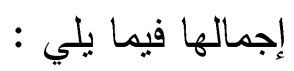

اولا : الأسس العلمية والتنظيمية :

يمكن القول بأن المنهج كنظام شأنه شأن الأنظمة الاخرى يُينى من أجل غاية أو مهمة

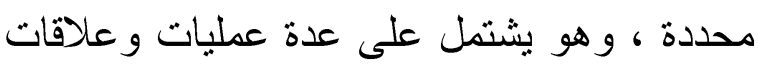

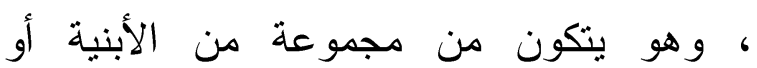

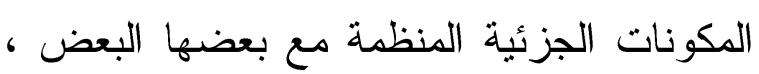

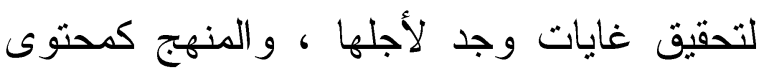

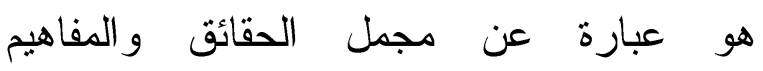
و المعلومات الخاصة بمادة علمية أو مقرر او وحدة او ثقافة يتبناها المجتمع ويراد صياغتها

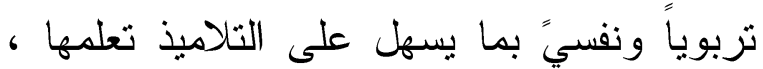
كما أن المنهج هو أداة المؤسسة التربوية

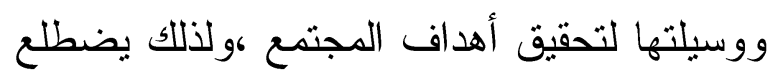

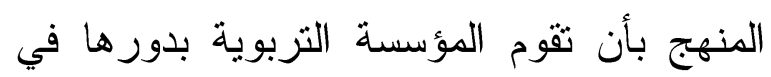

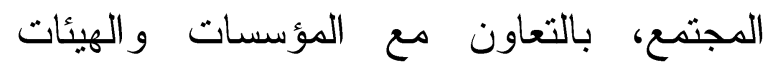
الاجتماعية الاخرى كالمساجد وكنلك الجهات الأمنية، وأن تكون العملية ذات تتظيم تحكمه المؤسسة التربوية من خلال تطبيق المنهج علمياً

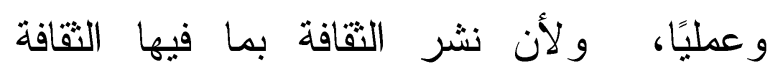
و التربية الأمنية جزء من المنهج المدرسي فإنه لا بد من بناء المنهج على اسس متعددة يجب الامن

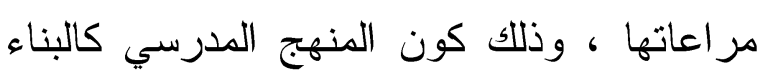

رابعا: يؤخذ بعين الاعتبار العامل النفسي، حيث

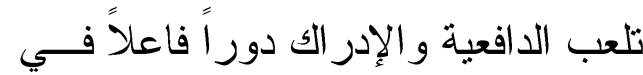

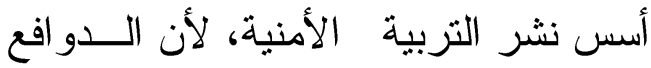

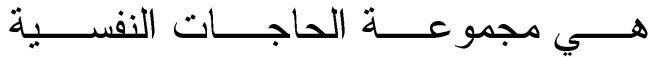
و الاجتماعية التي تشكل المثير ات الداخلية و الخارجية في سلوك الفرد و استجاباته. خامسا: مر اعاة المنطلقات العقائدية و الاجتماعية و الزمانية في تتظـــيم محتــوى التزبيـــة

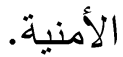
سادسا : أن يتصف تتظيم المحتوى بالمرونة

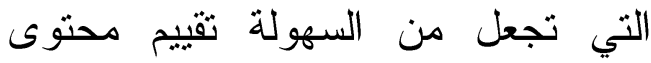
وبرنامج التربية الأمنية مستمر اً. ولإجابة على سؤال الاراسة الثاني و الأي نصه " ما المرتكزات العلمية التي يُبني عليها لتواليه مقترح تخطيط نشر التربية الأمنية في لفئية المؤسسات التربوية في ضوء الاتجاهات الحليثة في بناء المناهج؟ تناولت التنظيمات و الاتجاهات التقليدية في بناء المناهج عند تنظيم المحتوى ما يُعنى بعقل المتعلم

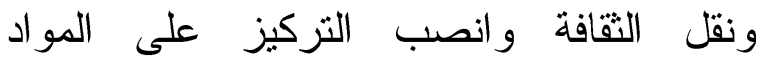
الدر اسية و أهملت ميول و اهتمامات المتعلمين،اما في الفكر الحديث فقد أصبح المتعلم هو محور الاهتمام ، فاهتماماته وميوله هي مصدر نموه التعليمي وركز على التعليم من خلال النشاط و المؤسسة التربوية ، وفي آخر التطورات في الفكر التربوي تم التركيز على المجتمع وحاجاته

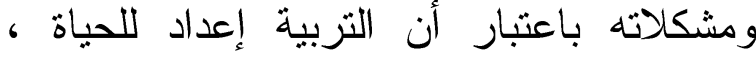
والتربية يجب الا تتم بمعزل عن المشكلات الحقيقية للحياة المعاصرة وأن وظيفة التزبية هي لهني 


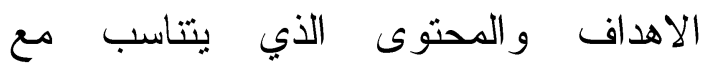
المراحل العمرية و انتقاء الوسائل و الأساليب المناسبة لها .

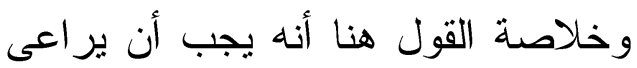

في اعداد المنهج وتخطيطه وتتفيذه، ووضع النه

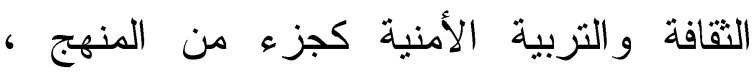
الأبعاد الفلسفية و والاجتماعية ولية الثقافية و السيكولوجية حتى تتحقق الغايات المنشودة من وراء ذلك ،ويتم تطويع المنهج المدرسي لتعزيز الثقافة والتربية الأمنية لاى الطلاب و والمساهمة في تحقيق تتمية المجتمع فيما يتعلق بالأمن بمفهومه الثامل . بان.

\section{ثانيا :التخطيط لبناء التربية الأمنية في المناهج :}

تعتبر عملية التخطيط عملية إدارية من أهم العمليات في بناء المنهج وتصميمه وتتظيمه وتتفيذه ، او تتفيذ أجزائه ومكوناته أو عناصره ونهاء ونهاء ،وللتخطبط مستويات فيمكن أن يتم التخطيط على مستوى الدولة من خلال وزارة التربية والتعليم أو على المستوى المحلي من خلال ادارات التزبية و التعليم أو على مستوى المؤسسة التربوية، وترجع أهية التخطيط في بناء المناهج

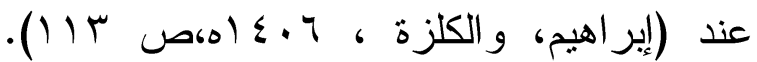

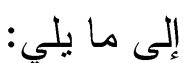

1-يساعد التخطيط في تحديد المجال الذي سيتم بناؤه، سواء خبرات تعليمية ضمن المناهج او أنشطة مصاحبة للمنهج r-يساعد تخطيط المنهج في وضع الأهداف

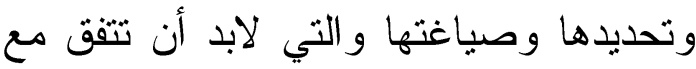

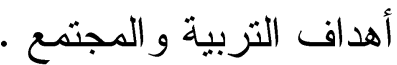

له اسسه وأركانه التي ينطلق منها أو يضعها المخططون في حسبانهم عند عملية البناء او التخطيط لذلك المنهج . ومن الأسس التي يجب مراعاتها عند وضع

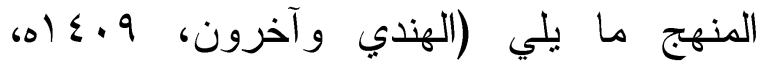

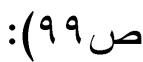
1-الأساس الفلسفي: حبـث يجــب أن يركـز المنهج المدرسي على فلسفة تربوية تعكسـس

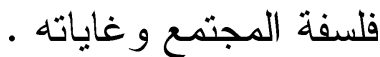

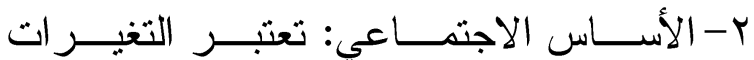

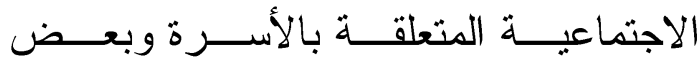
الجماعات الاخرى التي تؤثر وتتأثر بالمنهج

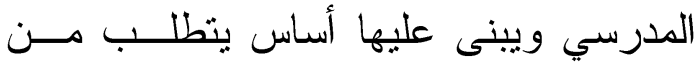

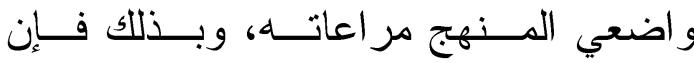
المؤسسة التزبوية مؤسسة اجتماعية حاضنة ومنفذة لهذا المنهج ويعبر وســياتها للقيــام

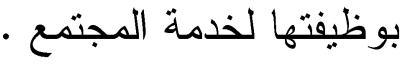
r-الأساس التقافي : تعتبر الثقافة نسيج معقد من الافكار و القيم و المعتقدات و العادات و التقاليد و الاتجاهات و السلوك وغير ها ، و الطفل يولد مجرد منها ويتم اكتسابها بالممارسة و المشاركة و التقلبد بطرق متعددة أهمها المؤسسة التربوية بكل عناصر ها بما في ذلك المنهج و أصبحت المؤسسة التربوية ضرورة اجتماعية في حياة الناس. ع - الأساس النفسي (السيكولوجي): عملية التربية

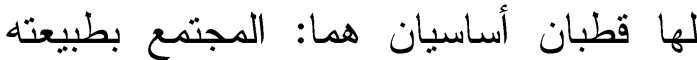
و أهدافه، والتلميذ بخصائص نموه الجسمي هيني

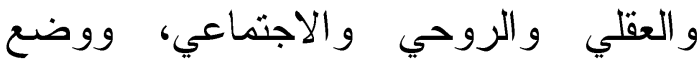


ع- المادة الار اسية ( المحتوى) ومر اعاة لثورة

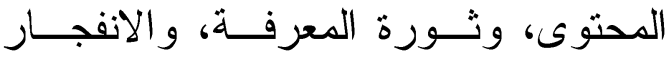

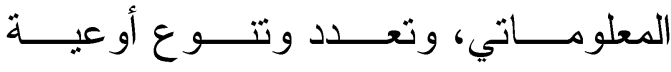

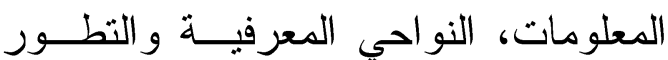
- العلمي - - سيكلوجية التعلم والاستعانة بعلم النفس لفهم طبيعة المتعلمين ومر اعاة الفروق الفردية وتحديد الظروف و الشروط الو اجب تو افرها لتحيق الأهداف التعليمية .

رابعا : معايير صياغة أهداف محتوى التربية الأمنية في المؤسسات التربوية : تستدعي سلامة اختيار الأهداف التربوية و التعليمبة مر اعاة مجموعة من المعايير او الشروط حتى تصبح مقبولة من الفئة

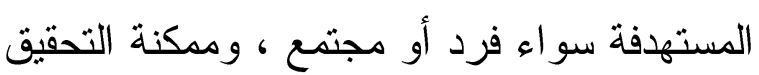
، كما أنها تتطلب تحليل واع ودقيق للمجتمع و الثقافة و وعملية التعلم وطبيعة المتعلمين وخلفياتهم وطبيعة التطور العلمي والاجتماعي والاقتصادي و السياسي ، ويمكن اجمال المعايير الواجب توافرها في أهداف محتوى الثقافة و التربية الأمنية في المؤسسات التربوية في ضوء نظريات المنهج فيما يلي(منصور و النجار

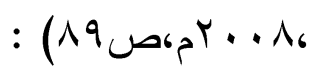

1 - أن تستتد الأهداف إلى فلسفة ثربوية اجتماعية سليمة : أي تتماشى هع فلسفة

$$
\text { وحاجاته وتحدياته المجتمع • }
$$

r- ان تكون الأهداف واقعية ، أي تكون ممكن تحقيقها في ظل و اقع المؤسسة التربوية وظروفها الحقيقية و الر اهنة. r- ير اعي حاجات المجتمع و المتعلمين .

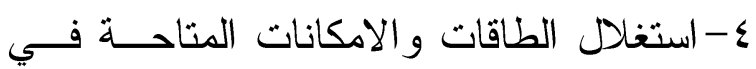
المؤسسات التزبوية . المبات

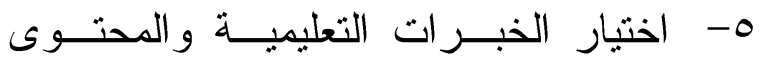
المناسب ويعطي مؤشر ات لتطبيق الأنشـــة العلمية المصاحبة .

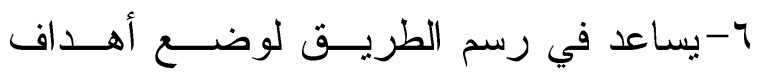
مرحلية جديده (مثل أهـــداف نشــر التقافــة

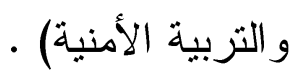

V- Vيساعد في اختيار طرق التـدريس و التنفيــذ و الوسائل المناسبة لتوصيل المحتوى. ᄉ-يساعد في عمليات تقويم المــنهج وطــرق الأداء وتقويم عملية التتفيذ .

\section{ثالثا : مصادر الشتقاق الأهداف التمليمية المتعلقة}

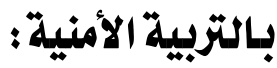

الاتجاه الحديث في بناء محتوى المناهج

والمقررات يرى أنه ليس هنالك مصدر واحد لنشتق منه الأهداف التعليمية ولكن يمكن القول بأن مجمل المصادر التي نشتق منها الأهداف التعليمية يمكن تحديده في العناصر التالية: 1- فلسفة المجتمع وقيمه ومبادئه، ووضع الفلسفة التربوية والتعليمية التي تعكس فلسفة المجتمع

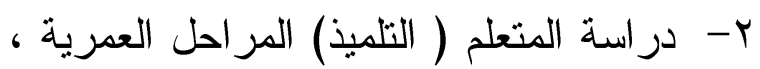
السلوك، الحاجات، الميول والقدرات

$$
\text { و الاستعداد . - الت }
$$

r- الحياة و البيئة المحلية بحكم تأثير ها وتأثز ها بالتغير ات الداخلية و الخارجية . 


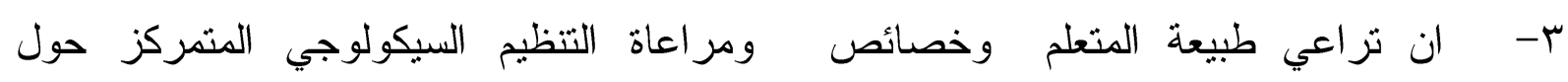

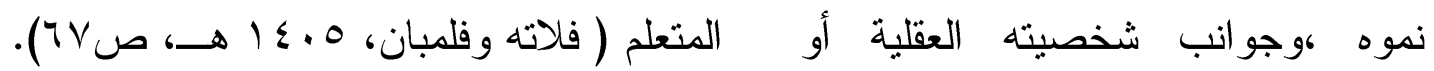
وييرز في عملية اختيار المحتوى الوجدانية أو الجسمية. اتجاهان ، الاتجاه الأول أن يتث اختبار أي مجال من المعرفة أو الثقافة العلمية المراد تقديمها للتلاميذ في نظام منطقي منتابع ، و الاتجاه الثاني

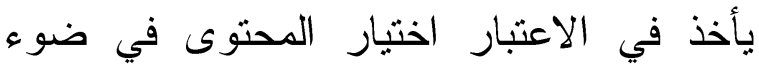
الأهداف المحددة للمنهج ، غير انه يمكن القول بأن عملية اختيار المحتوى ليست عملية محدودة، بل كثيرة الأبعاد، كما أن عملية تحديد الأهداف

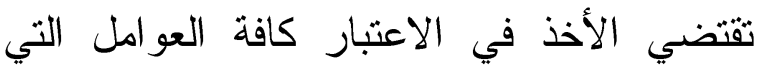

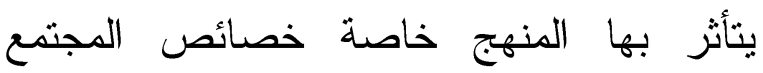
و التطور ات الحادثة فيه . باتئ

وفي ضوء ذللك فإنه يمكن أن يخضع اختيار محتوى الثقافة والتزبية الأمنية في المؤسسات التزبوية لبعض المعايير التي يمكن اجمالها فيما

1-أن يرتبط محتوى الثقافة والتربية الأمنية بالأهداف التي تم وضعها في ضوء الحاجة

$$
\text { اليها. }
$$

r-صحة وحداثة المعارف و المعلومات التي تم

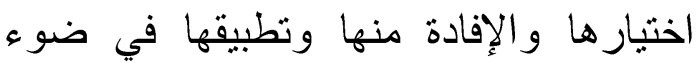
تطبيق صدق المحتوى ودلالاته . r-أن يرتبط المحتوى بميول وحاجات وحياة المنعلمين وو اقعهم. ع-أن يتم التوازن بين المجالات المعرفية التي

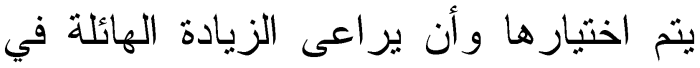
حجم المعارف والمعلومات المراد اليصالها - للمتعلم ع- - أن تساير هذه الأهداف مطالب العصر

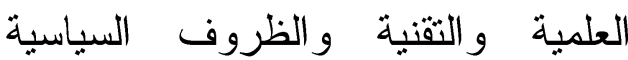
و الاجتماعية و الاقتصادية. 0- ان تصاغ بشكل سلوكي ، بحيث يمكن

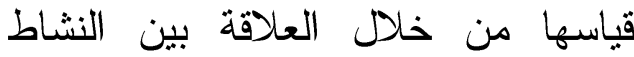
العلمي في المؤسسة التربوية والتغير المرغوب في سلوك الطلاب . צ- أن يشارك في وضع أهداف محتوى الثقافة والتزبية الأمنية كل من له علاقة الهات في تحديدها ووضعها ، وتحقيقها.

خامساً : اختياروتتظيه وتصميه محتوى التربية الأمنية بما فيها الأنشطة اللامنهجية ؛ تعتبر عملية اختبار المحتوى من أصعب المر احل في تصميم وبناء المنهج ، لأنها تتطلب دراسة دقيقة للمجتمع و المتعلم وطبيعة العملية التربوية و التعليمبة بجميع عناصرها وتحديد العلاقات بينها وكذلك دراسة المستجدات العصرية بجميع أثكالها او ما يتعلق بالتسارع المعرفي، وهناك معايير يجب مر اعاتها في ذلك بلك تتمنل في أهداف المنهج، وعملية التعلم ، وميول التلاميذ، والفروق الفردية ومراحل النمو ومشكلات المحتوى وتتو عه. كما أن عملية تنظيم المحتوى وتحقيق التز ابط و التكامل بين أجزائه يتطلب التنظيم أو أو التسلسل المنطقي المتمركز حول المعرفة الجديدة 
أجله، وتعد المؤسسة التربوية من المؤسسات التي تسهم في تعزيز المواطنة لدى الطلاب، مما

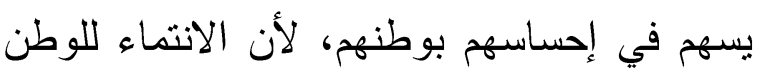

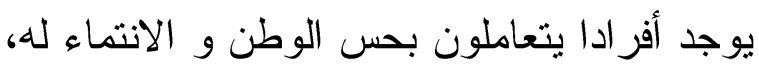

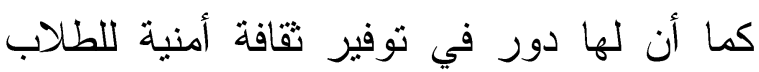
تبصر هم من خلالها ببعض أنماط السلوك التي توفير التئه يمكن أن تؤدي إلى عدم انحر افهم ، ويتحقق ذلك الكاط لئل عن طريق المنهج الصفية و اللاصفية . وفي ضوء ذللك يمكن أن تقوم المؤسسات التربوية باعتبار ها مؤسسات نربوية تعليمية بما

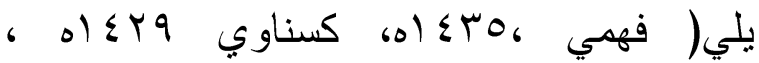

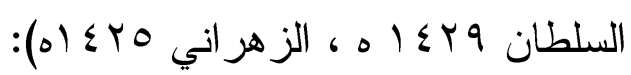
ا ـ تخصيص مقررات تُعني بالتزبية الأمنية

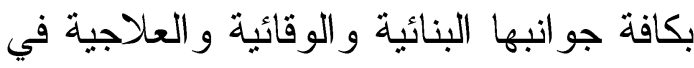
المؤسسات التربوية ، وكذلك كليات الجامعة

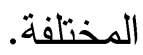

r. تخصيص برامج في الأنشطة في المؤسسات التزبوية تعنى بالجوانب الأمنية للوطن و المو اطن وتتمي فيه الحس الأمني، وتثارك

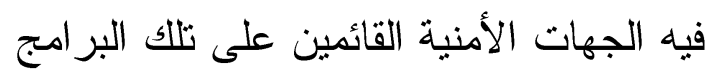
سو اء في وضع محتو اها أو عمليات تتفيذها. r. تخصيص أيام للتعريف بالقطاعات الأمنية المختلفة في المجتمع داخل المؤسسات التربوية و الجامعات.

ع. تقديم النشرات و الدوريات الأمنية وجعلها جزءاً من المكتبة المدرسية أو الجامعية. ه. تضمين المناهج الدراسية النواحي الأمنية الوقائية، وفي الوقت نفسه حث الطلاب على الطى
0- مراعاة تعقيدات التنظيم المنطقي في في التدرج من الجزء إلى الكل ومن البسيط إلى المركب ومن السهل إلى الصعب و التنظيم التئ ومن التيطي السيكولوجي ونظريات التعلم وقو انينها لأهميتها في تفسير عملية التعلم . 4-مر اعاة تحديد استراتتيجيات التدريس المناسبة لتحقيق الأهداف وعملية التعلم و التعليم بما فيها نشاطات ومشاركات المتعلم وفاعليته في التعلم و التعليم . V أن ير اعى كفايات الظروف البيئية و المدرسية في تحقيق الأهداف التعليمية المتعلقة بالتربية الأمنية في المحتوى التعليمي. وقد ظهرت تتظيمات عديدة وكل تتظيم أو الو لتيدئ تصميم المنهج منها ماهو متمركز حول المادة

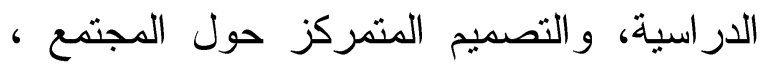
و التصميم المتمركز حول الطفل، و التصميم المتمركز حول النشاط أو الخبرة ، والتصميم المتمركز حول الكفايات ، و التصميم الدحوري .

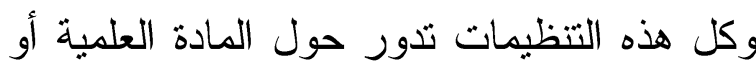
الدراسية (المعرفة)، أو ت تدور حول التلميذ (المتعلم) او تدور حول ( المجتمع ) )

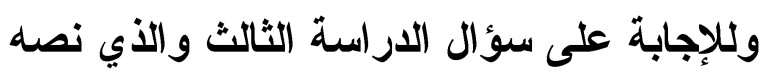
" ما دور المؤسسة التربوية في الحفاظ على لئل المجتمع في ضوء مبادئ تخطيط نشر التربية

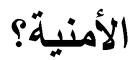
يقع على عاتق المؤسسة التزبوية مسئولية نشر التربية بمختلف أثكالها و إثاعة السلوك التربوي و التعليمي و العلمي الأساسي لتئي تحقيقاً لأهداف المجتمع الذي نعيش فيه ومن ولني 
ويمكن القول بأن دور المؤسسة التزبوية كهيئة تربوية تعليمية يكمن في تقديم الرعاية النفسية للطلاب ومساعدتهم على حل مشكلاتهر والاعتماد على أنفسهم وكيف يحققون أهدافهم بطرق تتسق مع الدعايير الاجتماعية، دع الاهتمام بالتوجيه و الإرشاد النفسي و التربوي و الديني و المهني، وكذلك بناء علاقة بين الطلاب على أساس من العدل و التشاور و التعاون و التوجيه السليم الذي يقوي تماسك مجتمع المؤسسة التربوية وبالتالي تماسك المجتمع الكبير وتوجيه النشاط الطلابي لخدمة الأمن ودعم القيم الإيجابية في المجتمع ، وتقديم نماذج للسلوك الاجنماعي المتحضر و الدقبول و الإشادة بالطلاب

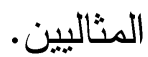

ويعتبر دور المعلم أساسي في تقليص الفجوة الفاصلة بين المؤسسة التربوية ومجتمعها المحيط بها، لأنه إذا سمح لهذه الفجوة بالبقاء والاتساع، فسوف تحرم المؤسسة التربوية من

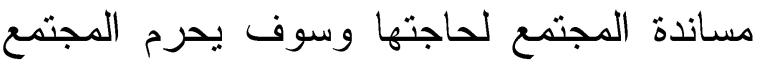
بدوره من خدمات المؤسسة التربوية ، وهذا وتتتوع مجالات عمل المعلم وتتعدد أدواره طبقا لظروف و إمكانات كل مدرسة على حدة، وكذلك طبقاً لظروف المجتمع المتغيرة، وهذه المجالات عبارة عن أنشطة وممارسات الهدف منها خدمة المجتمع بتحقيق التمية الثاملة في جوانبها المختلفة الاقتصادية والاجتماعية و السياسية

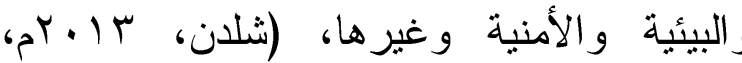

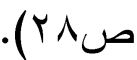

القيام بمساعدة السلطات المختصة بالقبض على الجناة عند وقوع جريمة. ד. الاهتمام بالتثقيف الأمني في مراحل التعليم المختلفة، و الذي يقوم على أساس تدعيم

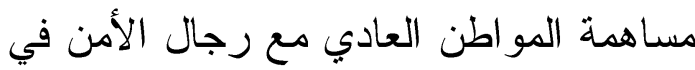
بعض الأحوال في تحقيق الأمن. V. أن تقوم المؤسسة التربوية بمواكبة التطور العالمي السريع و المذهل، ويكون ذلك بتزويد طلابها بالمعلومات والخبرات التي تمكنه من كثف الأنشطة الإجرامية المختلفة المرتبطة بالتطور التكنولوجي. ^. التوعية بأنواع العقاب الإسلامي الثرعي، الثرعي، بما يؤدي إلى الامتتاع عن الإجرام، قال تعالى: "ولكم في القصاص حياة با أولي

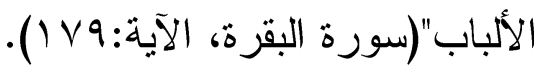
9. توعية الطلاب بضرورة احترام رجل الأمن الابن في أي مكان و اليقين بأنه يؤدي واجباً مكلفاً به للحفاظ على الأمن و الكثف عن جريمة وقعت، و أن يتعاونو ا معه ويسهلو ا مهيته. • ا. توعية الطلاب بعدم السكوت عن الجرائم التي يشاهدونها والإسراع بالتبليغ عنها و الإدلاء بالثهادة دون خوف أو ارتباك.

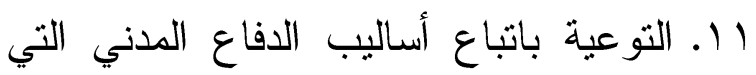
توفر للطلاب السلامة. r ا. الدعوة للمساهمة في حملات التوعية التي تقوم بها الأجهزة الأمنية لشرح قوانينها كقانون المرور و الوقاية من حوادث السير، ومضار المخدرات وحماية الطفولة و العنف في الملاعب الرياضية وغير ها. 
ع. تضمين محتوى المقررات تتمية مهارات

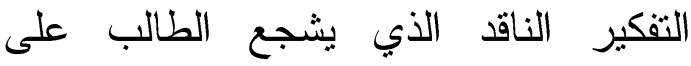
الالتزام بالفكر السوي وتقبل الرأي الآخر .

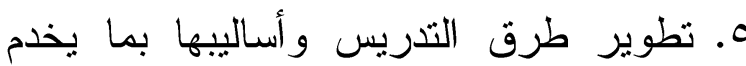
انتاج مخرجات ناضجة وو اعية وقادرة على تمييز الصواب ونبذ الخطأ والتطرف. T. تضمين كتب الثقافة الإسلامية وسطية الإسلام وسماحته و واحترام الآخرين، وتوضيح ما يتعلق بالسيرة النبوية وكيفية التعامل مع المخالفين وتأسيسه للأكن الفكري

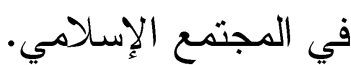
V. إدر اج محتوى يعزز ثقة الطلاب في أنفسهر وتقوية قدر اتهم وتتمية دهار اتهم بما يؤدي إلى نمو الثجاعة الفكرية في شخصيته، و وتثجيع الطلاب على عمل بحوث تعزز الأمن الفكري وحب الانتماء للوطن ودمج الفكر الوسطي المعتدل وحب الوطن في المناهج الدر اسية.

^. تضمين المناهج ما يخدم تحقيق الاحتياجات

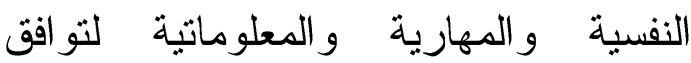
احتياجات الطلاب وتساعد المؤسسة التربوية على تحقيق اهدافها وتفعيل دور النشاط المدرسي بصورة تحقق احتياجات الطلاب ومتطلباتهم وتسهم في تتمية مهار اتهم وتحقق

$$
\text { فرص الإبداع و الابتكار لايهم. }
$$

9. تضمين المناهج الدراسية القيم الأخلاقية والاجتماعية بما يؤثر على تصرفاتهر وتحميهم من الانحراف وتحثهم على القيام بالتعاون مع رجال الأجهزة الأمنية في ربط عن العيط
وللإجابة على سؤال الاراسة الر ابع والذي نصه " ما الاستراتيجيات والمقترحات المناسبة لتطبيق مبادئ تخطيط التربية الأمنية في المؤسسات التربوية بهدف المساهمة في تحقيق الأمن بمفهومه الثامل ؟ . قام الباحث باستعر اض الاستر اتيجيات و المقترحات المناسبة لتفعيل تطبيق التربية

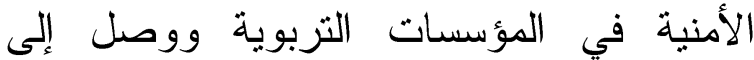
التالي: في ضوء التغيرات الثقافية والاجتماعية الداخلية والخارجية كان لزاماً على الدول عن طريق مؤسساتها التزبوية والتعليمية وضع أهداف استراتيجية شاملة لنشر التربية الأمنية بهدف إثاعة الوعي بين كافة فئات المجتمع لهان بأهية الأمن و انعكاساته على المجتمع وتوحيد رؤى الثقافة والتربية الأمنية، ولذا يضع الباحث الاستر اتيجيات التالية في ضوء التحليل الوثائقي للار اسات السابقة و المصادر التي اعتمد عليها في إعداد الدر اسة:

\section{اولا : استراتيجيات مرتبطة بـالمنهج :}

ا. إدر اج موضوع التربية الأمنية ضمن المناهج

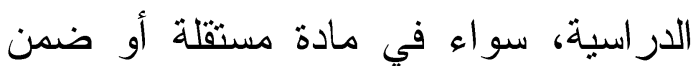
المواد على أن تكون المادة متسمة بالوضوح و الشفافية . r. الاهتمام بنشر نقافة الحوار في المقررات . r. إدراج تقافة المحبة والتسامح ضمن الدقررات في ظل تعاليم الإسلام السمحة. 
يعزز الثقة في نفوسهم ويستغل قدر اتهم فيما يفيد

9 9. إقامة معارض دائمة في المؤسسات التربوية توثق للأمن الفكري وتتظيم زيارات دورية للطلاب لهذه المعارض. •. . تفعيل مجالس الحوارات المدرسية في

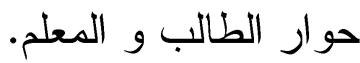
11. التأكيد على دور المؤسسة التربوية في توجيه الفكر وحمايته من الأفكار الضالة .

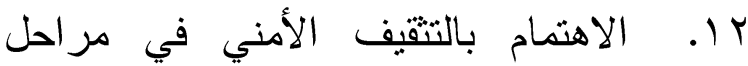
التعليم العام المختلفة وغرس مفهوم التعاون

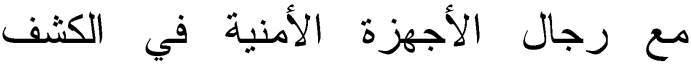

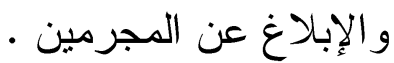
rا. تفعيل دور المشرف الاجتماعي و المرشد الطلابي بما في توجيه النصح و الإرشاد للطلاب بمخاطر الجريمة وبأهمية التعاون مع رجال الأمن لنشر النوعية والثقافة وباهية

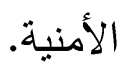

ثالثاً: استراتيجيات مرتبطة بالمثاركة المجتمعية : المانمان

1. استثمار المناسبات الدينية و الوطنية في تعزيز الأمن الفكري.

r. وضع خطة عمل لتطبيق الميثاق من خلال المؤسسة التربوية و المؤسسات الخيرية. r. تعزيز فكرة حب الوطن وتتمية مبدأ الانتماء له و استثمار مكانة الوطن ومنجز اته ع. ايجاد شراكات حقية بين المؤسسات التربوية و الجمعيات الخيرية والاجتماعية للقبام بمشاريع مشتركة مثل مكافحة التدخين
التوعية الأمنية بالمقررات الدراسية مع استغلال المواد المختلفة والأنشطة المدرسية و الرحلات و الندوات وبرامج التوعية و الإرشاد في التوعية الأمنية.

ثانيا : استراتيجيات مرتبطة بعمل المؤسسات التزبوية المستمر:

1. تكثيف البرامج التوعوية التي تحذر من الترن الارهاب و إثر الك الطلاب جميعهم في هذه

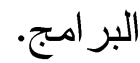
r. تشجيع المؤسسات التربوية التي تطبق البرامج الوطنية التي تسهم في تعزيز الأمن

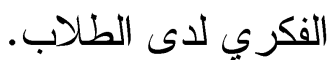
r. تخصبص أسبوع للتوعية بالأمن الفكري لإل على غرار الأسابيع التوعوية الوطنية. ع. تكليف الطلاب بعمل مشاريع تطوعية لربط

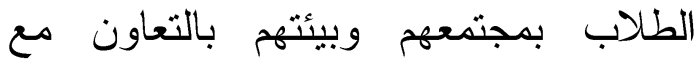
المؤسسات الاجتماعية بحيث يمكن قياسها وتعزيز ها. 0. استقلال مر اكز مصادر التعليم لكي تعد مو اد وثائقية تحذر من الارهاب على أن تكون مشوقة وبأسلوب مناسب. ד. تخصيص وقت للحوار المفتوح اسبوعيا للطلاب لمناقثة المواضيع المهمة لديهر وتتمية جانب الاعتدال في شخصياتهم. V. الاهتمام برصد سلوك الطلاب في المؤسسات التزبوية وتتبع انو اع التصرفات المنحرفة في بداياتها قبل أن تستفحل في نفس الطالب. ^. الاهتمام بهموم الطلاب دون تميز بينهم لأجل تفاوت قدر اتهم العقلية و التحصيلية بما 
المناشط المدرسية الالكثرونية التي تعمل على علاج أسباب الإزهاب بأنواعه ومنها الإزهاب الالكتروني ونشر و و إعلان العقوبات المترتبة على استخدامات الانترنت غير المشروعة وتأسيس مر اكز خاصة لعلاج و إعادة تأهيل المتورطين في الجرائم

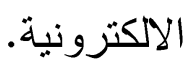

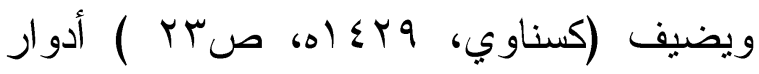
استراتيجية أخرى هن الممكن للمؤسسات التربوية القيام بها لنشر التوعية والثقافة والتربية

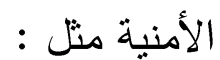
ا. ثربية الأبناء على احتر ام رجال الأمن وحثهم على التعاون معهم وتسهيل مهامهم . Y. تضمين المناهج الدراسية مفاهيم الأمن و الاستقرار على أن تهدف المناهج الدراسية إلى غرس روح المسئولية الفردية و الجماعية

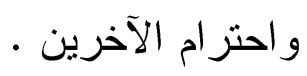

r. ينبغي تعميم مادة حقوق الإنسان في جميع المراحل الدراسية لغرس مفهوم الحقوق

$$
\text { و الو اجبات . }
$$

ع. ينبخي تطوير مقررات التزبية الوطنية لتشمل مفهوم الدولة وأمنها ، ومفهوم التوعية و التقافة و التربية الأمنية وأهميتها وكيفية تفعيلها ودور المواطن في نشر هذا المفهوم إضافة إلى موضوعات متخصصة في

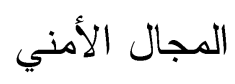

0. تضمين المناهج الدراسية معلومات عن الجر ائم وكيفية مكافحتها ، ومخاطر الارهاب

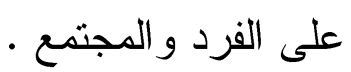

0. تشجيع وتشيط المواقع الصالحة التي تدعو إلى الوسطية و الاعتدال ونبد التطرف و العنف و إنشاء المواقع الاككترونية التي تتيح فرصة الحوار الرشيد. 7. انتاج مواد إعلامية تعريفية بالإسلام وقيم مجتمعنا الحقيقية بما يظهر الصورة المشرقة لنا أمام الآخرين والانطلاق من المرجعية الشرعية في تحديد شخصية المسلم المعتدلة و البعيدة عن التطرف و الغلو . V. تفعيل دور لجان الأمن الفكري في المجتمع

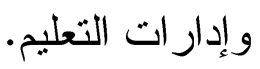
^. توعية الجمهور من خلال المؤسسة التربوية بمسؤولية كل واحد في الرقابة على هذا المجتمع وعدم وقوع أي سلوك منحرف وله مهما كان نو عه وصورته.

\section{رابعاً:استراتيجيات مرتبطة بـالتدربب والتنمية :}

ا. التأكيد على دور الرقابة المؤسسية و الذاتية لدى المعلمين و إقامة بر امج تدريبية للمعلمين في تتمية مهار ات التفكير و الحوار و التو اصل و إعداد وتصميم حقائب تدريبية في الأمن الفكري وتتفيذها على المعلمين. r. تفعيل دور المرشدين التربويين في المؤسسات التربوية لتحصين عقول الناشئة

$$
\text { من الوقوع في التطرف و الارهاب. }
$$

r. الاهتمام برفع مستوى كفايات المعلم لتعزيز

$$
\text { دوره في الأمن الفكري. }
$$

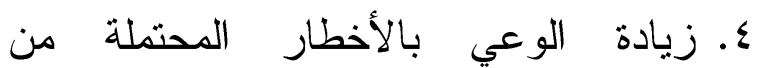
الانترنت ومعالجة العو امل التي توفر أرضية خصبة للإزهاب الاككتروني والتركيز على 
ويعني تطبيق برنامج التربية الأمنية بصورة

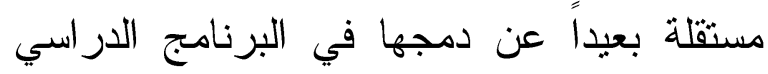
اليومي، مما يعني تخصيص وقت من أوقات اليوم الدراسي لتطبيق التربية الأمنية، بحيث تشترك كل من الجهات الأمنية والجهات التربوية و التعليمية في وضع برنامج للتقافة الأمنية ويتم تتفيذه من خلال التكامل بن هذه الأجهزة في

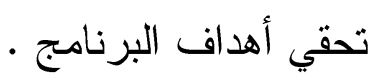
r - أسلوب الامج أو التكامل:

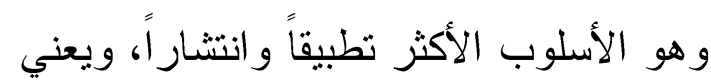
تطبيق التربية الأمنية ودمج مفاهيمها وأهدافها

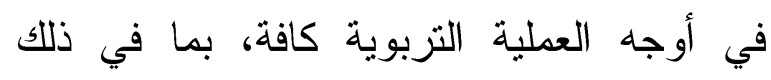

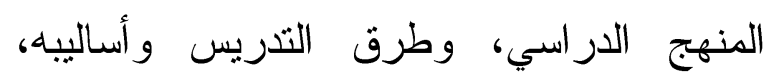
ومحتوى المادة الدراسية، و والأنشطة الطلابية ولية ولئه

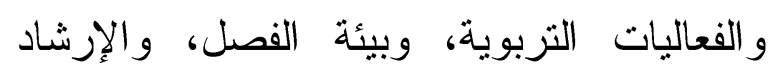
الطلابي، و أساليب الإدارة التربوية، وغير ذلك ولكئل

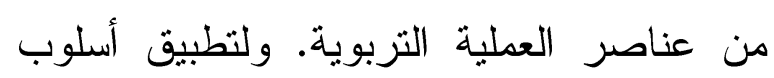

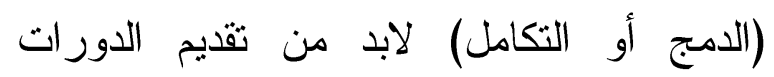

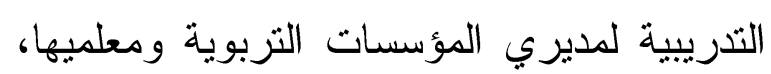
وللمعنيين بتطبيق التربية الأمنية في المؤسسات التزبوية؛ وذلك لاستبعاب المفاهيم والنطبيقات

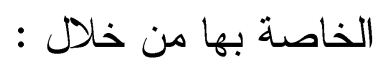

$$
\text { أولاًا - المنهج الدراسي: }
$$

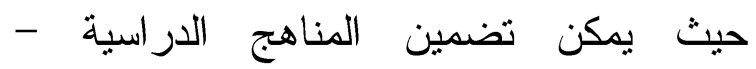
وخصوصاً المقررات الدر اسية-كثير اً من الأبعاد الخاصة بالتربية الأمنية. ويتوفر في المؤسسة التسنة

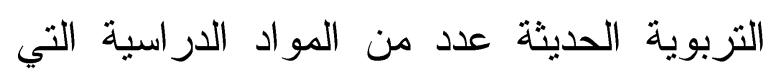
يمكن استثمارها في غرس كثير من القيم

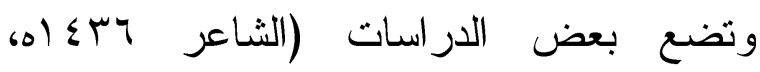

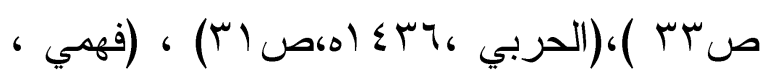

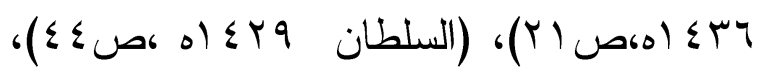

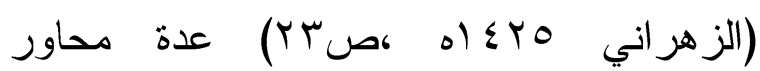
لإستر اتيجية مقترحة لتطبيق التربية الأمنية في المؤسسات التربوية.

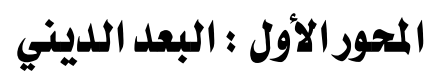

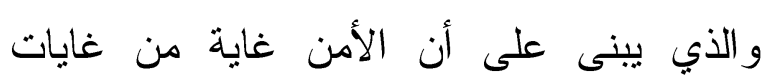
الإسلام ، و لا يمكن أن يحقق الإسلام رسالته

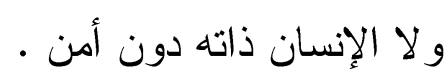
المحور الثاني : البعد الثقافي ويبنى على أساس تعزيز الحس الأمني لدى الدى الطلاب، وتتمية الثقة و التفاهم و الاحتر ام المتبادل بين رجال الأمن و الطلاب. المحور الثالث: البعد الوقائي ويينى على أساس توفير الحماية والدعم من خلا التدابير الاحترازية لتمكين الطلاب من وند ممارسة حقوقهم.

\section{المحور الرابع : البعد الأمني.}

ويينى على أساس تأصيل الانتماء والولاء

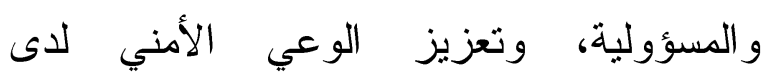

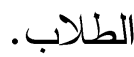

\section{ثانيا : تطبيق الاستراتيجية :}

حيث تشير هذه الدراسات إلى أن تطبيقات

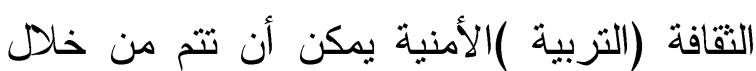

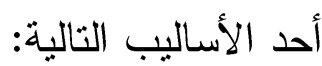
1- الأسلوب المستقل: 


\section{رابعاً- المحاضرات الأمنية والتوعية:}

حيث يمكن تظبيم برنامج تعاوني يتم تطويره من قِبِل جهات ومؤسسات التعليم و الجهات الأمنية، إذ يتم وضع خطة سنوية يتولى من خلالها عدد من الضباط و المختصين في الجهات الأمنية تقديم محاضرات عن الدور و المهام العظيمة لرجال الأمن في مكافحة الجريمة والإزهاب، وكذلك الحاجة إلى تعاون أفر اد

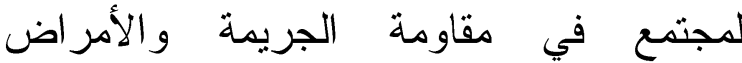
الاجتماعية المختلفة التي تؤدي إلى زعزعة الأمن واستقر ار المجتمع ومكافحتها.

\section{خامسا- - زيـارة المرافق الأمنية:}

من المهم تتظيم زيارات يتم تتسيقها بين الجهات الأمنية و إدار ات التعليم لبعض المرافق الأمنية منل: مر اكز الأجهزة الأمنية أو مر اكز البحوث الأمنية أو السجون أو غيرها من المرافق التي تعطي الصورة الإيجابية للجهد الكبير الذي يقوم به رجال الأمن للحفاظ على مقدر ات الوطن ومكنسباته الوطنية.

سادساًا - إدارة المؤسسـات التربوية : يعتمد تطبيق التربية الأمنية على المستوى المدرسي على مدى تفاعل مدير المؤسسة التربوية وقناعته ، وبدون توافر هذه القناعة المهنية و الشخصية لمدير المؤسسة التربوية سوف يصبح من الصعوبة بمكان تطبيق ممارسات التربية الأمنية بصورة ناجحة. ولذا فإنه من المهم جدا تقديم البرامج و الدورات التدريبية لمديري المؤسسات التربوية
والاتجاهات الإيجابية، إضافة إلى ما تتضدنه مفاهيم التزبية الأمنية و أهدافها. ثانياً- النشاط ارلامنهجي: ويمكن من خلال برامج النشاط الطلابي الآتية تفعيل مفاهيم التربية الأمنية من خلال :

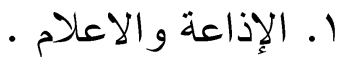

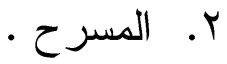
r. جمعيات النشاط الطلابي . ع. الصحف وصفحات الإنترنت وشبكات

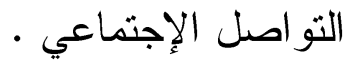
ثالثاً - الإرشاد الطلابي: حيث يلعب الإرشاد الطلابي دوراً مهماً في إنجاح برامج التربية الأمنية من خلال تعزيز التو اصل بين الأسرة و المؤسسة التزبوية، إضافة إلى معرفة أحوال الطلاب الذين يعيشون ظروفاً غير طبيعية، منل الميل للعنف و التطرف، أو القابلية لانحر اف أو تعاطي المخدرات، مع إعداد بر امج مساعدة لهم، بالإضافة إلى الاستفادة من المناسبات التربوية والتعليمية للتعريف بالتربية الأمنية، وبالأخطار الفكرية والاجتماعية التي يتعرض لها الطلاب، وكذلك تفعيل قواعد السلوك و المو اظبة، و استكمال إجر اءات تتفيذها، فضلا عن تعريف المجتمع التربوي والتعليمي (طلاباً ومعلمين) بآليات تتفيذ التربية الأمنية، و أساليب ضبط سلوكيات الطالب السلبية و الحد منها. 
1- تفعيل دور الأسرة مــن خــال المنــاهج و المقرر ات و الأنشطة الصفية و اللاصــفية

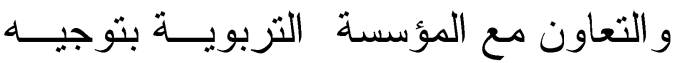

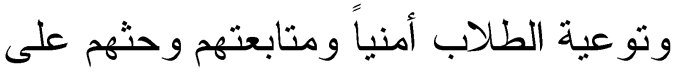

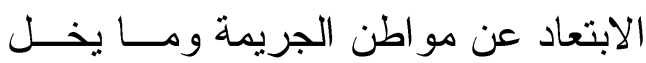

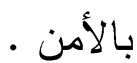
9- اجر اء در اسات ميدانية حول و اقع المناهج

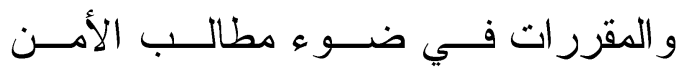

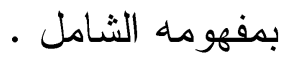
• 1- إجر اء در اسات عن و اقع بيئة التعلم و التعليم

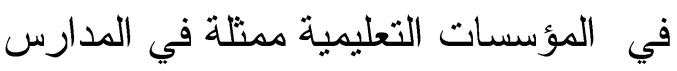
و الجامعات السعودية ومدى اسهامها فــي تحقيق مطالب الأمن بمفهومه الثامل .

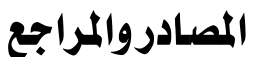

$$
\text { 1- القرآن الكريم • }
$$

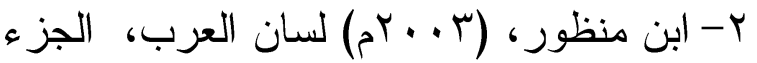

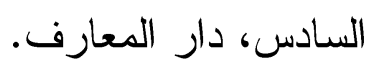

ץ- ابر اهيم ، فوزي و رجب الكلزة (ך . أهـ) ،المناهج المعاصرة ، مكة المكرمة ، مكتبة

$$
\text { الطالب الجامعي . }
$$

ع- بركات وجدي محمد و السيد، عمار مصطفى وعبدالرحمن، هبة اله (1... آم). شرطة

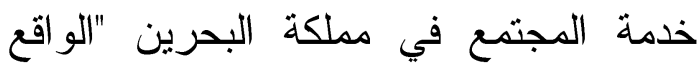
و المستقبل" : نحو استر اتيجية مجتمعية أمنية

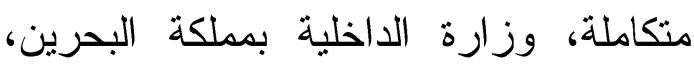
الأكاديمية الملكية للشرطة: مركز البحوث

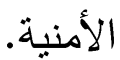

0- الحربي،محمد احمد(ب الهـ اهـ)، إستر اتيجية مقترحة لتحقيق التكامل بين الأجهزة الأمنية المدابية
لتدريبهم على مفاهيم التربية الأمنية، والوصول إلى الكفايات المهنية اللازمة لتطبيقها بصورة فاعلة، وتحويلها إلى سلوكيات الثقافة و التربية

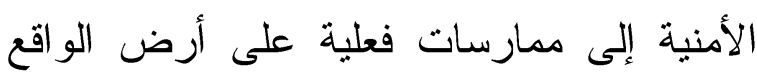
من خلال عناصر العملية التعليمية بالتسيق و التخطيط و المتابعة المستمرة .

\section{توصيات ومقترحات الدراسة:}

1- تحليل المناهج الدراسية في التعليم العام في الدول العربية بما يتوافق مع اســتراتيجية التخطيط لنشر التربية الأمنية.

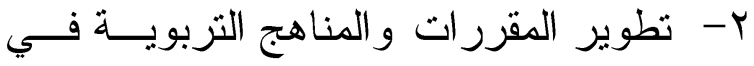
الدول العربية في ضـــوء نظريــات بنـــاء المناهج بما يحقق أهداف التوعية و التربية الأمنية. ץ- التخطـ بط لتصــميم محتــوى المقـررات و المناهج بما يتو افق مع قيم و احتر ام الر أي

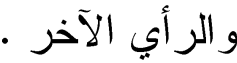
ع- تعزيز دور مؤسســات المجتهــع المــني وتفعيل دورها مع المؤسسات التربوية بما يتو افق مع أهمية تحقيق أهداف نشر الثقافة و التزبية الأمنية. 0- التركيز على القيم الإنسانية فـي تصــميم محتوى المقررات المدرسية التي تؤدي إلى الى تكوين مشاعر الانتماء الــوطني وزيـــادة اللحمة و المودة و التفاعل مع مجتمعهم.

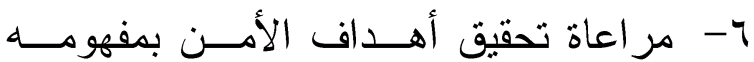
الثامل عند تصميم المناهج المدرسية.

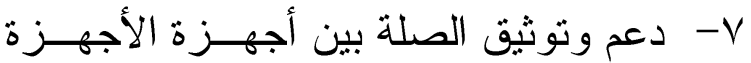
الأمنية و الأفر اد و المؤسسات التربوية. 
المؤسسات التربوية الثانويــة ومشــرفيها ومديريها، جامعة الملــلك ســـود: مركــز

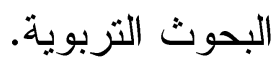

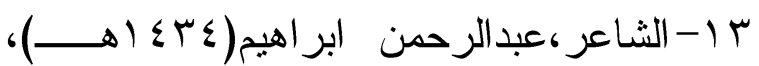
التقافة و التربية الأمنية المفهوم و الواقــع جامعة نــايف العربيــة للعلـــوم الأمنيــة،

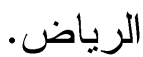

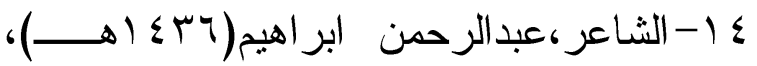

القيم المعززة للوحدة الوطنية في مراحـل التعليم العام ،ندوة العلاقة التكامليـــة بــين الأجهزة الأمنيــة و التربويـــة فـــي الــبلاد العربية، جامعة نــايف العربيــة للعلــوم

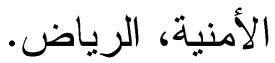

10-شلدن، فايز (rا +rام). دور كليات التربية بالجامعات الفلسطينية في تعزيــز الأمــن الفكري لدى طلبتها وتنظيم تفعيله، مجلــة الجامعة الإســلامية للار اســات التربويـــة و النفسبة

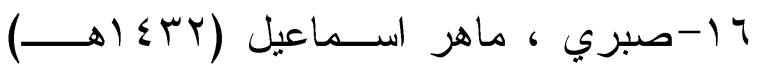
در اسة تحليلية لو اقــع مجـــالات التوعيــة الأمنية بمحتوى مقــرر ات التعلــيم العـــام بالمملكة العربية السعودية ،ندوة المجتمـع المع و الأمن في دورتها السادسة التوعية الأمنية

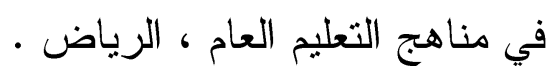
IV (ال) مصفوفة التوعية الأمنية في السلم التعليمي

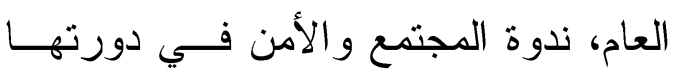

و المؤسسات التربوية في المملكة العربية السعودية، ندوة العلاقة التكاملية بين الأجهزة الأمنية و التربوية في البلاد العربية ، جامعة نايف العربية للعلوم الأمنية، الرياض.

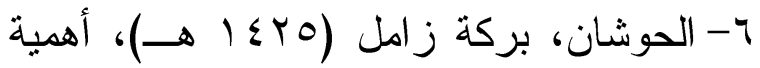

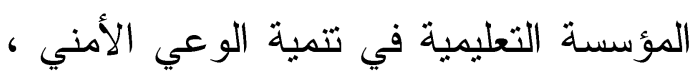
ندوة المجتمع والأمن ،كلية الملك فهذ الأمنية

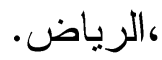

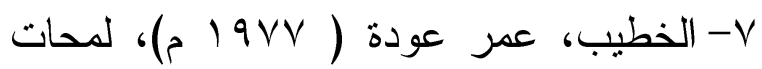
في الثقافة الإسلامية، بيروت ،مؤسسة

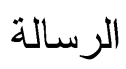
^- دليل مؤتمر التعليم و الأمن في الوطن

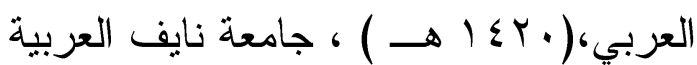
للعلوم الأمنية .

9- الرشدان ،عبداله ونعيم جعنيني(r + . rم) ، المدخل الى التربية و التعليم ، الاردن ،

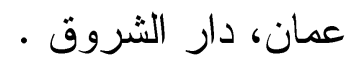

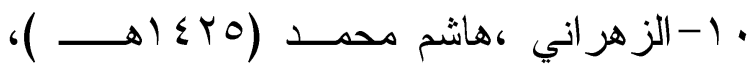
المؤسسات المجتمعيـــة و الأمنيــة : رؤي الزيـ مستقبلية، لندوة المجتمع والأمن المنعقــدة كلية الملك فهد الأمنية ،الرياض . 1 1-السلطان، فهد سلطان (99 (اهـ)، التربية الأمنية ودور ها في تحقيق الأمن الــوطني، بحث مقدم إلــى النــدوة العلميـــة "الأمــن

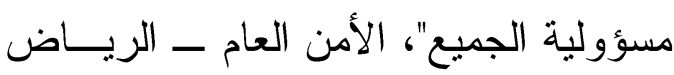

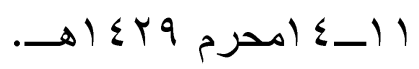
r ا السلطان، فهد سلطان (•rی (اهـ)، التربية الأمنية و إمكانية تطبيقها فـي المؤسسـات التعليمية: دراسة ميدانيــة علــى معلمـــي 


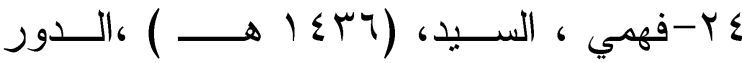

التربوي الأمني للجامعات ومر اكز البحـث

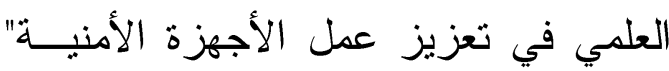

جامعة نــايف العربيــة للعلــوم الأمنيــة نموذجا"، ندوة العلاقة التكاملية بين الأجهزة الأمنية و التربوية في البلاد العربية ، جامعة نايف العربية للعلوم الأمنية، الرياض.

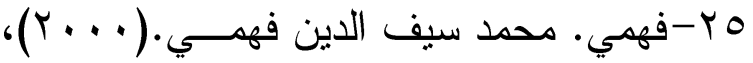
التخطيط التعليمـي، الانجلــو المصــرية،

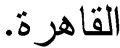

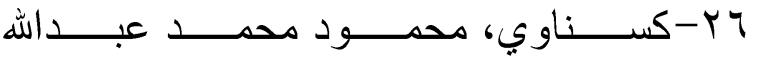

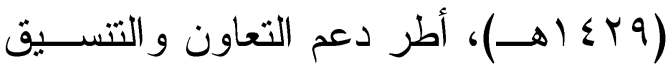

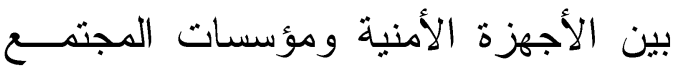
(الأسرة و المؤسسات التعليمية) لنشر مفهوم الثرطة المجتمعية، الأمن العام: ندوة الأمن

مسئولية الجميع "الثرطة المجتمعية".

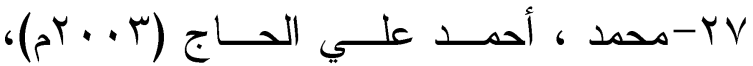
أصول التربية ، عمان، دار المناهج ،ط ؟ ك.

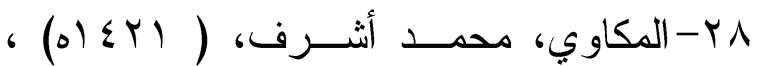

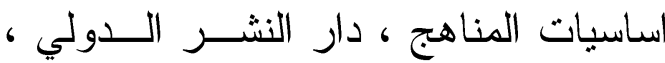

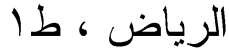

9ץ-الهندي ، صـالح ذياب ،و هثــام عليــان

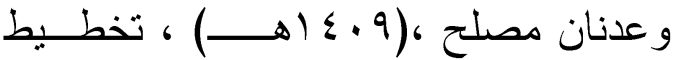
المنهج وتطـــويره الاردن ، عمـــان ، دار

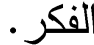

• ب-اللقاني ،احمد حسين ،وعودة ابـو سـنينة

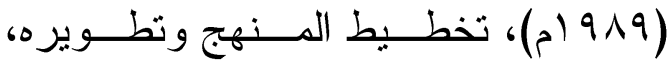
عمان، الدار الأهلية .ناصر ، إبــراهيم :
السادسة التوعية الأمنية في مناهج التعلــيم

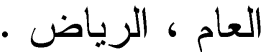
11-العادلي، محمود صالح (דبـ (هـ)، دور المؤسسات التزبوية فــي تعزيـز عهـلـل الأجهزة الأمنية في الوطن العربي ،نسـدوة لعان

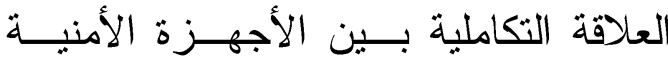
و التزبوية في البلاد العربية ، جامعة نايف العربية للعلوم الأمنية، الرياض.

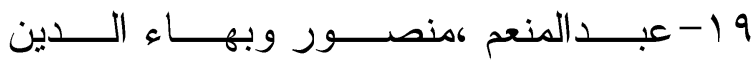

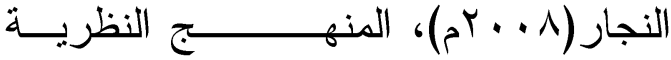

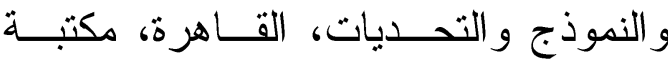
الأنجلو المصرية ،طب.

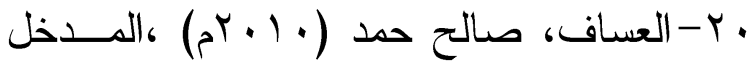
إلى البحث في العلوم السلوكية الريــاض،

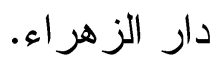

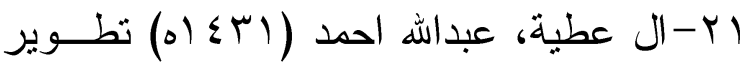
المناهج الدراسية فــي ضــو مـ منطلبـات المعرفة كرؤية مقترحة ، اللقاء الســنوي للجمعية السعودية للعلوم التربوية و النفسية (جستن) ، تطوير التعليم : رؤى وندــاذج لنعان ومتطلبات ،جامعة الملك سعود، الرياض.

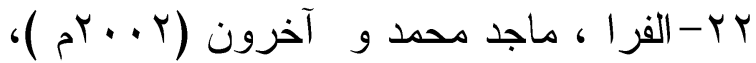

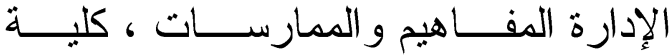
التجارة، الجامعة الإسلامية، فلسطين ،غزة، $.1 \mathrm{bc}$ ب ب-فلاته ، ابر اهيم محمود ، وفلمبــان ســير نور الــدين (0. 1 هــــ) ، الاتجاهـات

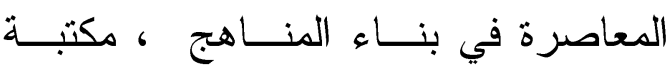
الفيصلية ، مكة المكرمة. 
الثانوية ، ندوة المجتمع و الأمن في دورتها السادسة التوعية الأمنية في مناهج التعلــيم

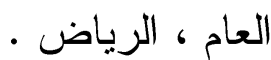

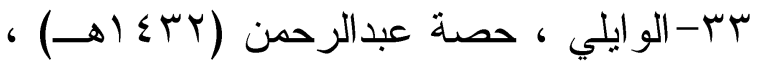
التوعية الأمنية في مناهج التعليم العـام ، ندوة المجتمع والأمن في دورتها السادســة التوعية الأمنية في مناهج التعليم العـام كله الرياض.
أسس التزبية، ط ب ، دار عمار ، عمـــان، $.1 \leq \cdot 9$ اب-النفيعي ، هالة عبد الله محمد(سبـ اهـ)، دور الإدارة المدرسية في تنميــة الثقافـة

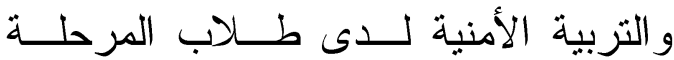
الثانوية بمحافظة الطائف ، رسالة ماجستير غير منشورة ، كلية التربيــة ، جامعسـة ام

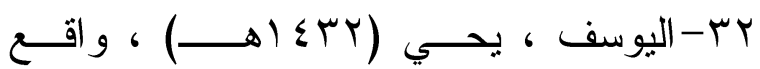
التوعية الأمنية في مناهج المؤسسة التربوية 